\title{
Stratigraphical distribution of Givetian ostracods in the type-area of the Fromelennes Formation (Fromelennes, Ardennes, France) and their relationship to global events
}

\author{
SÉbastien Maillet, Claudia Dojen \& Bruno Milhau
}

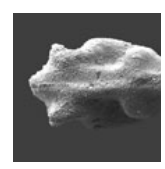

\begin{abstract}
Bed-by-bed sampling of three sections (Flohimont, Cul d'Houille and Nichet) exposing almost the entire Fromelennes Formation (Devonian, Middle and Late Givetian) in the historical type-area of the Givetian (Givet, Ardennes Department, France) provided more than 12,000 benthic ostracods. A high ostracod biodiversity is reported in these sections; 113 taxa are recognized of which 2 species are new: Acratia lucea sp. nov. and Orthocypris? cristae sp. nov. The stratigraphical distribution of the ostracods shows the installation of a Givetian fauna close to the base of the Fromelennes Formation with many endemic taxa and its disappearance as well as its subsequent replacement with more cosmopolitan taxa at the top of the formation with Frasnian affinities. This distribution is closely related to the major events of the Middle and Late Givetian in the Ardennes: the transgression pulse at the top of the Mont d'Haurs Formation, the global Taghanic Biocrisis and the global Givetian/Frasnian sea level rise. Climate change at the end of the Givetian possibly amplifies the effects of the sea level rise. The pattern of disappearance of many ostracod taxa in the Middle Givetian and their replacement by a new fauna as early as the Late Givetian is at least a supraregional phenomenon. Orthocypris? cristae sp. nov., Kielciella arduennensis Adamczak \& Coen, 1992, Jefina kaisini Coen, 1985 and Cavellina rhenana Krömmelbein, 1954 are considered as regional to supraregional stratigraphic markers. We establish the presence of a Middle Givetian ostracod province on the Givetian carbonate platform. $•$ Key words: ostracod province, palaeogeography, Fromelennes Fm. stratotype, Taghanic Biocrisis, regional extinction, faunal renewal, new species, Givetian carbonate platform, Devonian.
\end{abstract}

\begin{abstract}
MAillet, S., Dojen, C. \& MilhaU, B. 2013. Stratigraphical distribution of Givetian ostracods in the type-area of the Fromelennes Formation (Fromelennes, Ardennes, France) and their relationship to global events. Bulletin of Geosciences 88(4), 865-892 (12 figures, appendix). Czech Geological Survey, Prague. ISSN 1214-1119. Manuscript received February 27, 2013; accepted in revised form August 15, 2013; published online October 30, 2013; issued October 31,2013

Sébastien Maillet (corresponding author), Laboratoire de Paléontologie Stratigraphique \& Laboratoire d'Ecologie \& Biodiversité, Faculté Libre des Sciences et Technologies \& Institut Supérieur d'Agriculture, Géosystèmes UMR 8217 CNRS, 41 rue du Port, F-59016 Lille cedex, France; sebastien.maillet@icl-lille.fr•Claudia Dojen, Landesmuseum für Kärnten, Museumsgasse 2, A-9021 Klagenfurt, Austria; claudia.dojen@landesmuseum.ktn.gv.at • Bruno Milhau, Laboratoire d'Ecologie \& Biodiversité, Faculté Libre des Sciences et Technologies, 41 rue du Port, F-59016 Lille cedex, France; bruno.milhau@icl-lille.fr
\end{abstract}

The Devonian is a period of dramatic climatic changes, during which Givetian greenhouse conditions change into icehouse conditions close to the Devonian/Carboniferous boundary (Caputo et al. 2008). This period is encompassed by the IGCP project 596 "Climate change and biodiversity patterns in the Mid-Palaeozoic". This paper contributes to the project by documenting the ostracod fauna and its biodiversity in the historical type area of the Givetian, spanning a period during which several environmental and climatic events took place. The Taghanic Biocrisis (House 1985, Aboussalam \& Becker 2011), a period of major fau- nal change around the Middle/Late Givetian boundary, as well as the global sea level rise and climatic and sedimentary changes close to the Givetian/Frasnian boundary are of special interest, as these events are reflected in the ostracod distribution.

The studied area is located within the Dinant Synclinorium, which is known for its excellent Devonian outcrops including the historical type area of the Givetian in the French Ardennes. The penultimate of the six formations of the classical Givetian (Bultynck et al. 1991, Bultynck \& Dejonghe 2001) is the Fromelennes Formation 


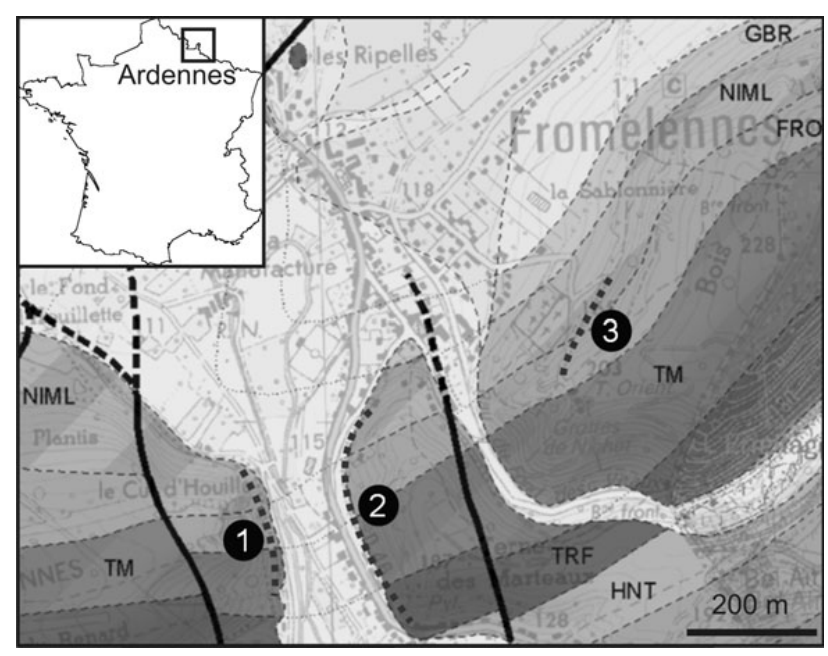

Figure 1. Locality map of the studied sections in the Fromelennes area. 1 - Cul d'Houille section; 2 - Flohimont section; 3 - Nichet section. Abbreviations: HNT - Hanonet Fm.; TRF - Trois-Fontaines Fm.; TM - Terres d'Haurs \& Mont d'Haurs Fms; FRO - Fromelennes Fm. NIML - Nismes \& Moulin Liénaux Fms; GBR - Grands Breux Fm.

(Fm.), whose ostracod distribution is studied in this paper. The stratotype of the Fromelennes Fm., composed of the Flohimont and the Cul d'Houille sections, and the recently newly described Nichet section (Maillet et al. 2011) have been sampled bed-by-bed. Together, these well-exposed sections cover the Fromelennes Fm. most completely across the entire historical type area of the Givetian. Although several studies on the Fromelennes fauna exist, ostracods from the Flohimont and the Cul d'Houille sections have not been studied in detail, and they have not been reported at all from the Nichet section. This study complements and advances existing ostracod studies from the area by presenting a detailed stratigraphical distribution. This distribution shows the combined effects of the Taghanic Biocrisis, the climate change during the Late Givetian and the sea level rise at the Givetian/Frasnian boundary which are confirmed by data from sedimentology (e.g. Préat \& Carliez 1994, Boulvain et al. 2009) and from other faunal groups (e.g. Coen-Aubert 2004; Pinte \& Mistiaen 2009, 2010; Maillet \& Milhau 2010). Thus, the study of the ostracods from the Givetian of the Ardennes not only reviews and complements the palaeontological knowledge on the Fromelennes Fm. in its type-area, but also confirms their value for understanding deep-time climate and environmental changes.

\section{Geographical and geological setting}

The three studied sections (Flohimont, Cul d'Houille and Nichet) are located in the "Pointe de Givet" natural reserve of the Ardennes Department in N France, about $3.6 \mathrm{~km} \mathrm{SE}$ from the town of Givet, near the village of Fromelennes
(Fig. 1). The Cul d'Houille section is located along the western bank of the Houille stream (N 50 $11^{\prime} 74^{\prime \prime}$, $\left.\mathrm{E} 4^{\circ} 85^{\prime} 52^{\prime \prime}\right)$, whereas the Flohimont section is sited east-

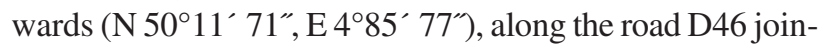
ing Fromelennes and Flohimont. The newly described Nichet section (Maillet et al. 2011) crops out along the way leading from Fromelennes to the Nichet cave (N 5007'19”, E 451' 51.5").

The Givet region is the type area of the Givetian and belongs to the southern part of the Dinant Synclinorium. The latter is located in the northern part of the Ardennes allochthon and forms a part of the Rhenohercynian belt of the Mid-European Variscides (Préat et al. 2006). In Givetian times, the area belonged to a wide carbonate platform (the "Givetian carbonate platform", see Boulvain et al. 2009, Préat \& Mamet 1989), which extended on the northern passive margin of the Rheno-Hercynian Ocean (Sintubin 2008) along the southern margin of Laurussia (Fig. 2).

Two major transgressive events can be recognized in the Middle and Late Givetian of the Givet area (Milhau 1983a, Casier 1987, Boulvain et al. 2009, Casier \& Préat 2009, Maillet et al. 2010, Maillet \& Milhau 2010). The first transgressive episode occurs around the Mont d'Haurs/Fromelennes Fms boundary, about $9 \mathrm{~m}$ below the base of the middle P. varcus ( $P$. ansatus) Zone (see Gouwy $\&$ Bultynck 2003). This transgression can be recognized everywhere in the Ardennes and also in the Boulonnais (around the Griset/Blacourt Fms boundary). However, according to Bultynck et al. (2001), it does not correspond to the global Taghanic Onlap (Johnson 1970, House 1975; $=$ transgressive episode IIa-Tagh in Aboussalam \& Becker 2011), as it is older. The second transgression is connected with a global sea level rise around the Givetian/Frasnian boundary, which leads to the collapse of the Givetian carbonate platform and the disappearance of its reefal barriers (Boulvain et al. 2009, Casier 1987).

Between these transgressive episodes, the global Taghanic Biocrisis took place, seriously affecting the neritic faunas and leading to the disappearance of the provincialism of the marine fauna (May 1995; Bultynck et al. 2001; Aboussalam 2003; Coen-Aubert 2004; Pinte \& Mistiaen 2009, 2010; Maillet \& Milhau 2010).

\section{Stratigraphic summary}

The Cul d'Houille and Nichet sections mainly expose the Fromelennes Fm., but both expose also the upper part of the underlying Mont d'Haurs Fm., and the Nichet section exposes the base of the overlying Nismes Fm. The Flohimont section is the most extensive, covering the entire Givet Group (composed of the Trois-Fontaines Fm., the Terres d'Haurs Fm., the Mont d'Haurs Fm. and the 


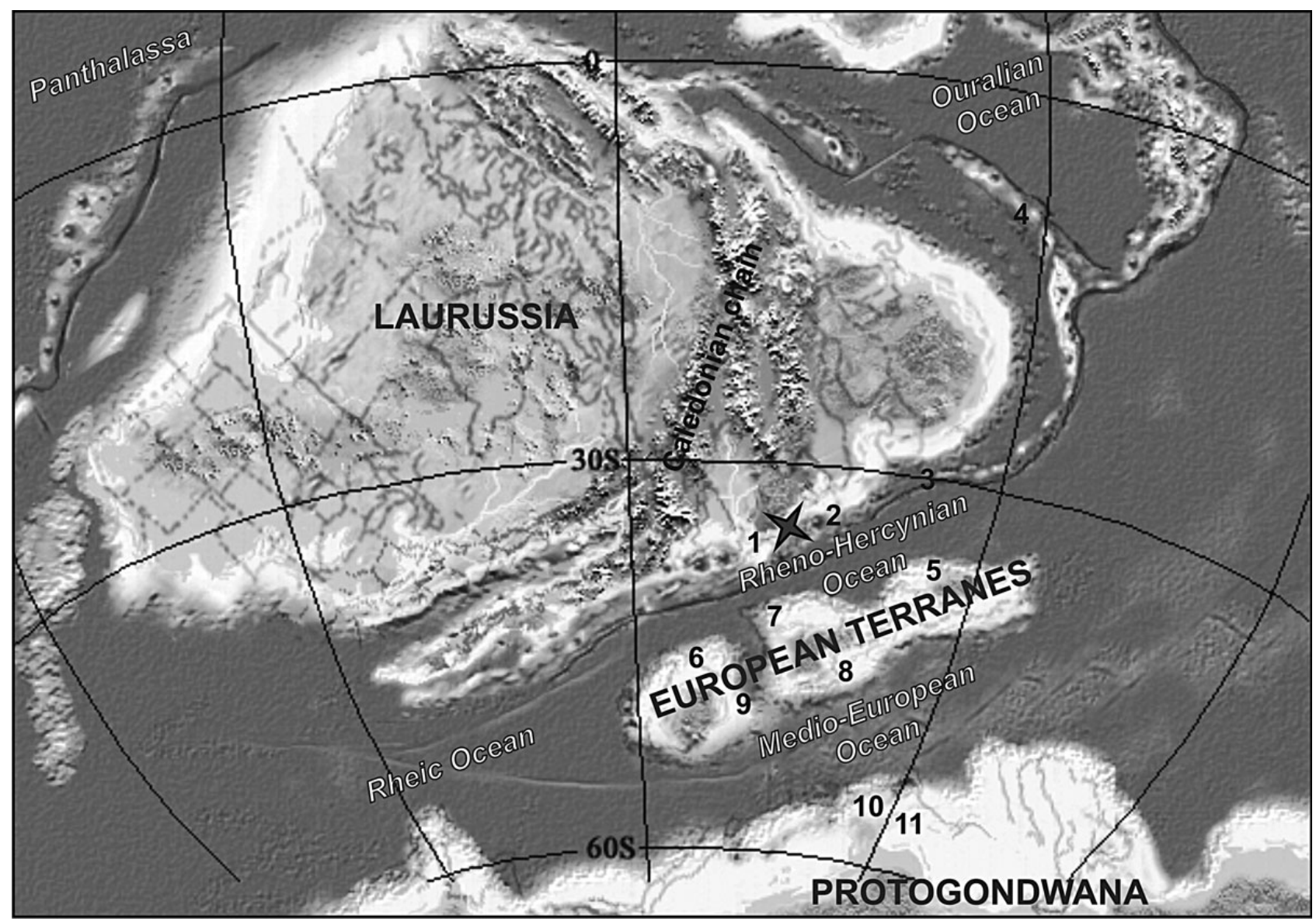

Figure 2. Middle Devonian palaeogeographic reconstruction (adapted from Blakey 2007). The star indicates the Ardennes location. 1 - Boulonnais; 2 -Eifel Hills, Sauerland and Bergisches Land; 3 - Holy Cross Mountains; 4 - Volga-Ural; 5 - Bohemian Massif; 6 - Asturias-Leòn; 7 - Armorican Massif; 8 - Montagne Noire; 9 - Mouthoumet Massif; 10 - Tafilalt; 11 - Ougarta Range.

Fromelennes Fm.) and the base of the Frasnes Group (base of the Nismes Fm.).

This paper is focused on the Middle to Late Givetian Fromelennes Fm. Due to faults and gaps, this formation is not completly exposed in any of these sections, but as they match very well, a composite stratigraphical column (Fig. 3) can be constructed. Likewise, the stratotype of the Fromelennes Fm. consists of the two complementary Flohimont and Cul d'Houille sections (Bultynck 1974, Bultynck et al. 1991). Detailed stratigraphical columns, faunal content and precise correlations of the sections as well as bed numbers for these three sections can be found in Hubert \& Pinte (2009) and in Maillet et al. (2010, 2011).

The upper part of the Mont d'Haurs Fm. consists of massive reefal limestones of protected and restricted environments. Near the top of the formation the environment became progressively more open, and argillaceous limestone beds were deposited, showing the beginning of a major trangressive episode at the base of the Fromelennes Fm. (Boulvain et al. 2009, Maillet et al. 2010). The part of the Mont d'Haurs Fm. studied herein is of early Middle
Givetian age and belongs to the lower Polygnathus varcus (Polygnathus rhenanus) conodont Zone.

The overlying Fromelennes Fm. is about 140 meters thick and consists of alternating argillaceous and massive reefal limestones of neritic origin with rare siltstones. The formation is subdivided into three members: the Flohimont Member (Mb.) at the base, the Moulin Boreux Mb. in the middle and the Hulobiet Mb. at the top. The thickness of the Flohimont Mb. is about $30 \mathrm{~m}$ (Bultynck 1974; Maillet et al. 2010, 2011) consisting of argillaceous limestone beds, which display a major transgressive period that started in the top of the Mont d'Haurs Fm. The Moulin Boreux Mb. is characterized by nearly $85 \mathrm{~m}$ of fine-grained limestones indicating a comparatively restricted and quiet environment during a regressive phase. Emersion surfaces with paleosols and ripple-mark levels can also be observed (Préat \& Carliez 1994, Boulvain et al. 2009). The Fort Hulobiet $\mathrm{Mb}$. consists of about $25 \mathrm{~m}$ of argillaceous limestones and shales deposited during a phase of sea level rise, initiating a second major transgression (Givetian/Frasnian boundary global transgression). The entire formation 


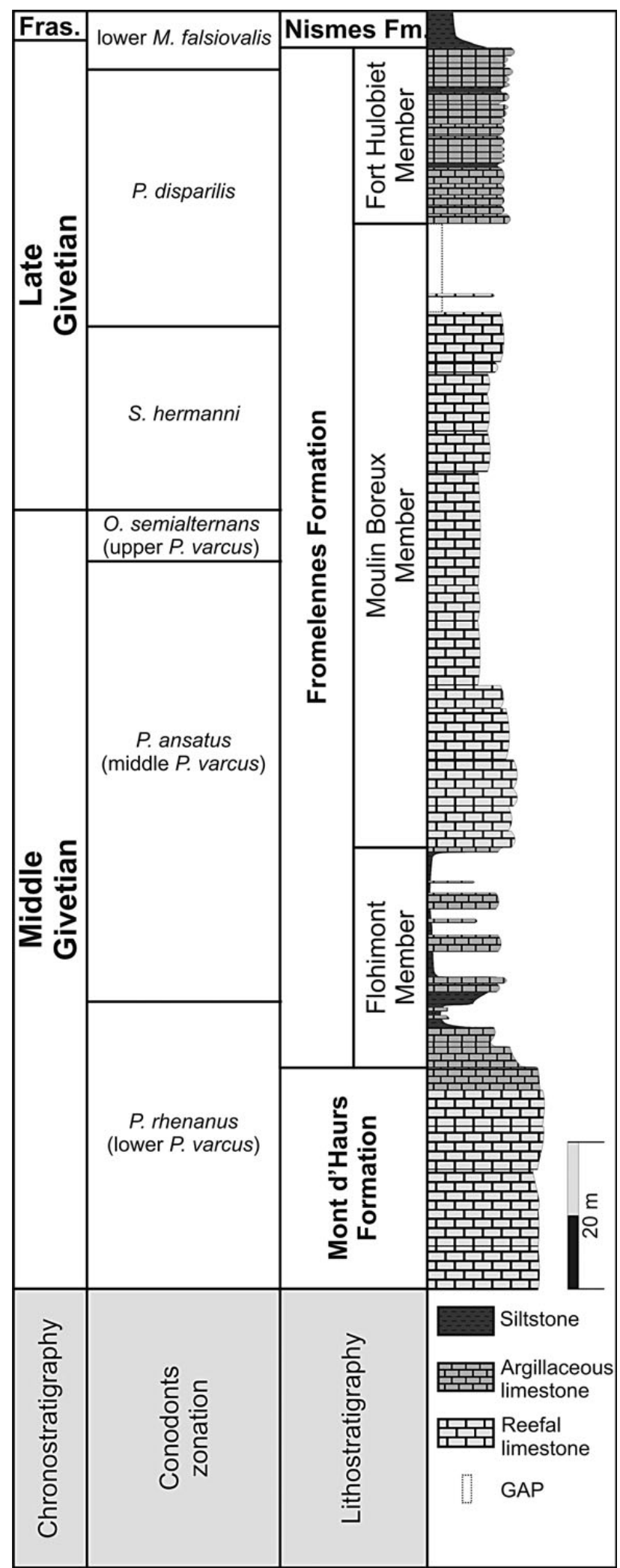

Figure 3. Fromelennes Formation composite stratigraphical column, standard conodont zonation and chronostratigraphy. encompasses the Middle Givetian (uppermost lower $P$. varcus Zone) and the Late Givetian (uppermost part of Klapperina disparilis conodont Zone) (Gouwy \& Bultynck 2003). The Middle/Late Givetian boundary is expressed by the transition from the upper $P$. varcus (Ozarkodina semialternans) to the Schmidtognathus hermanni conodont Zones (Gouwy \& Bultynck 2003), as well as by the last occurrence of stringocephalid brachiopods in the lower part of the Moulin Boreux Mb. (Coen-Aubert 2004, Bultynck et al. 2001).

The overlying base of the Nismes Fm. is represented by less than a meter of siltstone, which is still of latest Givetian age (uppermost $K$. disparilis to lower Mesotaxis falsiovalis conodont Zones). The base of the Frasnian is reported in the first meter of the formation by Narkiewicz \& Bultynck (2010) with first conodonts of the genus Ancyrodella (A. binodosa, A. pristina and A. rotundiloba), but could not be identified with certainty in the studied sections. However, position of the G/F boundary in the Ardennes is still in discussion (Casier \& Préat 2009, Casier et al. 2013). Initially suggested to be in the lower part of the Nismes Fm., it is now believed to be closer to the lithostratigraphical boundary between the Fromelennes and the Nismes Fms. However, the occurrence of Polyzygia beckmanni beckmanni in the base of the Nismes Fm. confirms an age close to the Givetian/Frasnian boundary.

\section{Previous work on ostracods from the Fromelennes Formation}

Middle Devonian ostracods have been studied from several areas of the Ardennes, but a comprehensive study on the ostracods from the stratotype of the Fromelennes Fm. and the additional Nichet section with a synthesis of their stratigraphical distribution is presented here for the first time. So far, the most complete study on these ostracods in the Flohimont and the Cul d'Houille sections was the preliminary work of Milhau (1983a, 1983b).

Besides the work of Milhau, Magne (1964) mentioned some ostracods from the Fromelennes Fm. in the $\mathrm{Cul}$ d'Houille section, Coen (1985) figured some ostracods from the Flohimont $\mathrm{Mb}$. in the Flohimont section, and Adamczak \& Coen (1992) used some ostracods from the Flohimont section for their study on the ontogeny and morphofunctional anatomy of the primitiopsids. As regards the Givetian of the Dinant Synclinorium, e.g., Casier (1987), Casier \& Préat (2009) and Casier et al. (2013) studied the stratigraphic distribution and palaeoecology of ostracods around the Givetian/Frasnian boundary. Casier et al. (2010b, 2011a, b) and Casier \& Préat (2013) did the same in the Early Givetian and reviews of Givetian ostracods have been compiled by Coen (1985), Casier (2008), Milhau (in Brice \& Mistiaen 2008) and Milhau et al. (2013). 


\section{Material and methods}

The three studied sections were sampled bed-by-bed except for the Moulin Boreux Mb. in which the lithofacies is unfavourable to collect ostracods (algal laminites, dolomitic limestones, emersion facies, etc.). About 12,350 carapaces, valves and fragments have been provided, of which about 8,900 specimens have been identified. In detail, there were:

- 7,100 ostracods within 113 out of 122 samples collected in the Cul d'Houille section.

- 4,900 ostracods within 111 out of 121 samples collected in the Flohimont section.

- 350 ostracods within 12 out of 15 samples collected in the Nichet section.

The calcareous ostracod valves and carapaces have been extracted from limestone samples by using the hot acetolysis method described, e.g., by Crasquin-Soleau et al. (2005). Images of gold plated specimens were made with the Environmental Scanning Electron Microscope (ESEM) Quanta 200 of the Université Lille1 des Sciences et Technologies. All samples are housed at the Faculté Libre des Sciences et Technologies of Lille. The figured material has been catalogued in the Collection d'Ostracodes de l'Université de Lille (C.O.U.L.); the individual numbers are indicated in the plate descriptions (Figs 4 to 8).

\section{Systematic palaeontology (by S. Maillet)}

In all, 113 ostracod taxa are reported, belonging to the orders Podocopida, Eridostracina and Palaeocopida, of which 42 are formally recognized and two new species are described (see below). All taxa are listed with their systematic position in the Appendix 1 and are figured (Figs 4 to 8).

Class Ostracoda Latreille, 1802

Order Podocopida Müller, 1894

Suborder Podocopina Sars, 1866

Superfamily Bairdioidea Sars, 1888

Family Bairdiidae Sars, 1888

\section{Genus Acratia Delo, 1930}

Type species. - A. typica Delo, 1930.

Diagnosis. - Bairdiidae "with highly arched dorsum and nearly straight ventral margin; anterior and posterior margin extremities located below mid-height; anterior end hook-like in shape, posterior end pointed" (Becker 2001, p. 272).

Range and occurrence. - (Lower) Devonian to Triassic, ?Upper Jurassic; worldwide (Becker 2001, p. 272).

\section{Acratia lucea sp. nov.}

Figure 4A-H

- 1964 Acratia sp. G1. - Magne, pl. 21, figs 102-104.

v•1983a Acratia sp. G1 sensu Magne (1964). - Milhau, pl. 1, fig. 27.

v• 1988 Acratia sp. G1 sensu Milhau (1983). - Milhau, pl. 55, fig. 35 .

v•1989 Acratia sp. G1 sensu Magne (1964). - Milhau in Brice et al., p. 122.

v 1991 Acratia sp. A. - Casier in Casier \& Préat, pl. 2, fig. 20.

v 2006 Acratia sp. G1 in Magne (1964). - Casier in Casier \& Préat, pl. 4, fig. 5a, b.

v ?2009 Acratia sp. indet. - Casier in Casier \& Préat, pl. 7, fig. 5.

v• 2010 Acratia lucea sp. nov. - Maillet, pl. 1, figs 1-8.

v 2011b Acratia lucea Maillet, 2010 nom. nud. - Casier in Casier et al., pl. 3, fig. 11.

v• 2013 Acratia lucea Maillet, 2010 nom. nud. - Casier \& Maillet in Casier et al., pl. 9, fig. O.

v• 2013 Acratia lucea Maillet, 2010 nom. nud. - Casier in Casier \& Préat, pl. 5, fig. 2.

Holotype. - Adult carapace (C.O.U.L. 501), $616 \mu \mathrm{m}$ in length, $362 \mu \mathrm{m}$ in height and $210 \mu \mathrm{m}$ in width (Figs 4A, 9).

Paratypes. - Three juvenile carapaces and one large adult carapace (C.O.U.L. 502, 504, 505 and 506), $394 \mu \mathrm{m}$, $535 \mu \mathrm{m}, 480 \mu \mathrm{m}$ and $822 \mu \mathrm{m}$ in length, $198 \mu \mathrm{m}, 246 \mu \mathrm{m}$, $242 \mu \mathrm{m}$ and $354 \mu \mathrm{m}$ in height, respectively (Fig. 4B, D, E and $\mathrm{F})$.

Type locality and type horizon. - Ardennes, Cul d'Houille section, Fromelennes Fm., Flohimont Mb. (Middle Givetian).

Material. - 26 carapaces, 4 valves and many fragments of juvenile and adult specimens.

Origin of name. - Lucea: latinized from "Luce", my girlfriend's first name to whom I dedicate this species for her field assistance.

Diagnosis. - A species of Acratia with a rather slender outline in lateral view (L/H ratio about 2:1). The valves are biconvex with a smooth surface. The dorsal margin is highly arched and has three convexity points. The ventral margin is convex with one distinct convexity point.

Description. - Slender carapace with an $\mathrm{L} / \mathrm{H}$ ratio of about 2 : 1; smooth surface; outline biconvex in lateral, dorsal and ventral views, anteriorly and posteriorly acuminate; posterior tip with slight ventral and dorsal concavities (Fig. 9); left valve larger than right, with dorsal overreach 
and ventral overlap each from the anterior to the posterior tip; bow-shaped projection on the closure line of the valves in ventral view; maximum length of carapace around twice the maximum of height; maximum width located at $2 / 5$ of the anterior end in dorsal view; maximum height anterior, at about $1 / 3$ of the maximum length; maximum length below mid-height, at about $1 / 3$ of the maximum height from the ventral margin; depressed hinge line centered with a length of $1 / 3$ of maximum length; dorsal margin highly arched with three distinct convexity points (Fig. 3): the first at about $1 / 6$ of the maximum length and about $3 / 4$ of the maximum height with an angle around $170^{\circ}$; the second at about $1 / 3$ of the maximum length and at the maximum height with an angle around $150^{\circ}$; the third at about $3 / 4$ of the maximum length and at about $3 / 4$ of the maximum height with an angle around $155^{\circ}$; ventral margin with one convexity point within the first anterior third with an angle around $135^{\circ}$, migrating towards the anterior during the ontogenetic growth.

Comparisons. - This new species is comparable only to two species which were both described from the Frasnian of the Russian platform: A. evlanensis Egorov, 1953, from the Voronezh and Yevlanovo beds, and A. schelonica Egorov, 1953, from the Shelon beds, but the new species differs from A. evlanensis by a less slender shape, a more strongly curved dorsal margin and a weaker ventral overlap, and from A. schelonica Egorov, 1953 by sharper ends and a dorsal overreach. A. luce a differs from all other Acratia species through its general outline, its pronounced dorsal overreach and ventral overlap, the $\mathrm{L} / \mathrm{H}$ and the $\mathrm{L} / \mathrm{W}$ ratios and the ventral and dorsal convexity points.

Occurrence. - A. lucea is present in the Ardennes in the Dinant Synclinorium in the Trois-Fontaines Fm., the Terres d'Haurs Fm., the Mont d'Haurs Fm. and the Fromelennes Fm. (Flohimont Mb. and Fort Hulobiet Mb.) and in the Namur Synclinorium in the Névremont Fm. The species is also present in the Boulonnais in the Blacourt Fm. (Griset $\mathrm{Mb}$. and Couderousse Mb.). A. lucea ranges from the $P$. he- miansatus to the $K$. disparilis zones of the standard conodont biozonation.

\section{Genus Orthocypris Kummerow, 1953}

Type species. - Bythocypris recta (Kummerow, 1943).

Diagnosis. - Bairdiidae with extremely elongate, cylindrically shaped carapace (Becker 2001, p. 286).

Range and occurrence. - Upper Silurian-Upper Devonian; Eurasia, China (Becker 2001).

Orthocypris? cristae sp. nov.

Figure $7 \mathrm{~A}-\mathrm{G}$

v•1983a Podocopina gen. indet. sp. A. - Milhau, pl. 1, figs 22, 23.

v 1983b Podocopina gen. indet. sp. A. - Milhau, pl. 10, figs 23-25.

v•1988 Podocopina gen. indet. sp. A. - Milhau, pl. 56, fig. 11.

v 2010 Orthocypris? bicarinata sp. nov. - Maillet, pl. 3, figs 10-14.

v 2013 Orthocypris? bicarinata Maillet, 2010 nom. nud. Casier \& Maillet in Casier et al., pl. 10, fig. J.

Holotype. - Adult carapace (C.O.U.L. 582), $494 \mu \mathrm{m}$ in length; $296 \mu \mathrm{m}$ in height and $269 \mu \mathrm{m}$ in width (Figs 7A, 10).

Paratypes. - One juvenile carapace and two adult carapaces (C.O.U.L. 583, 585 and 587), $380 \mu \mathrm{m}, 608 \mu \mathrm{m}$ and $491 \mu \mathrm{m}$ in length, $269 \mu \mathrm{m}, 368 \mu \mathrm{m}$ and $298 \mu \mathrm{m}$ in height, respectively (Fig. 7B, D and F).

Type locality and type horizon. - Ardennes, Flohimont section, Fromelennes Fm., Flohimont Mb. (Middle Givetian).

Material. - 16 juvenile and adult carapaces.

Figure 4. Ostracods from the Fromelennes area. Abbreviations: CHL - Cul d'Houille section; FLO - Flohimont section; DV - dorsal view, VV - ventral view, lv - left valve, rv - right valve; MH - Mont d'Haurs Fm.; FRfl - Fromelennes Fm., Flohimont Mb.; FRmb - Fromelennes Fm., Moulin Boreux Mb.; FRfh - Fromelennes Fm., Fort Hulobiet Mb.; NSpa - Nismes Fm., Pont d'Avignon Mb. For the bed numbering, see Hubert \& Pinte (2009) and Maillet et al. (2010, 2011). • A-H - Acratia lucea sp. nov.; A - holotype, CHL, 102''a FRfl, lv, C.O.U.L. 501; B - paratype, CHL, 92' 'bs, MH, lv, C.O.U.L. 502; C-CHL, 109'’c, FRf1, rv, C.O.U.L. 503; D - paratype, CHL, 190, FRfh, rv, C.O.U.L. 504; E1 - paratype, CHL, 109'”c, FRfl, lv; E2 - DV, C.O.U.L. 505; F - paratype, FLO, 130, FRfl, rv, C.O.U.L. 506; G - FLO, 113a, MH, VV, C.O.U.L. 507; H - CHL, 110' 'b, FRfl, rv, C.O.U.L. 508. - I - Acratia sp. A, FLO, 113b, MH, rv, C.O.U.L. 509. • J - Aechmina sp. A, FLO, 120, FRfl, rv?, C.O.U.L. 510. • K - Amphissites aff. parvulus (Paeckelmann, 1913), FLO, 50', FRfh, 1v, C.O.U.L. 511.•L - Amphissites cf. tener Becker, 1964, CHL, 85' 'st, MH, lv, C.O.U.L. 512.・M1 - Ampuloides sp.1 sensu Milhau, 1983, CHL, 92'’b, MH, rv; M2 - VV, C.O.U.L. 513. • N - Asturiella sp. A, FLO, 89', NSpa, lv, C.O.U.L. 514. • O, P - Bairdia paffrathensis Kummerow, 1953; O-FLO, 126, FRfl, rv, C.O.U.L. 515; P-CHL, 179, FRfh, rv, C.O.U.L. 516. • Q - Bairdia cf. plicatula Polenova, 1952, CHL, 85', MH, rv, C.O.U.L. 517.• R - Bairdia cf. siliklensis Rozhdestvenskaya, 1962, FLO, 123, FRfl, rv, C.O.U.L. 518. • S - Bairdia sp. A, FLO, 102a, MH, rv, C.O.U.L. 519. • T - Bairdia sp. B, FLO, 90', NSpa, rv, C.O.U.L. 520. • U - Bairdia sp. C, FLO, 124, FRfl, rv, C.O.U.L. 521. • V - Bairdia sp. sensu Coen, 1985, CHL, 207/208, FRfh, rv, C.O.U.L. 522.•W - Bairdiacypris aff. breuxensis Casier \& Olempska, 2008, FLO, 89', NSpa, rv, C.O.U.L. 523. $・ \mathrm{X}-$ Bairdiacypris sp. A, CHL, 90”, MH, rv, C.O.U.L. 524. • Y - Bairdiacypris sp. B, CHL, 215, MH, rv, C.O.U.L. 525. 

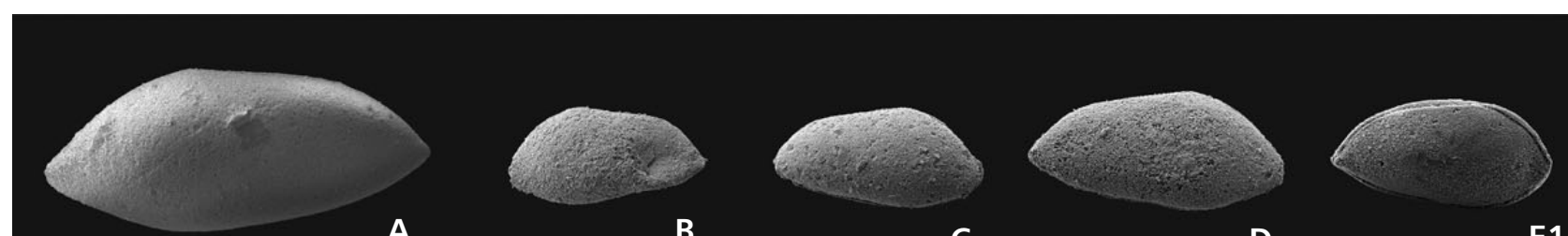

C

D
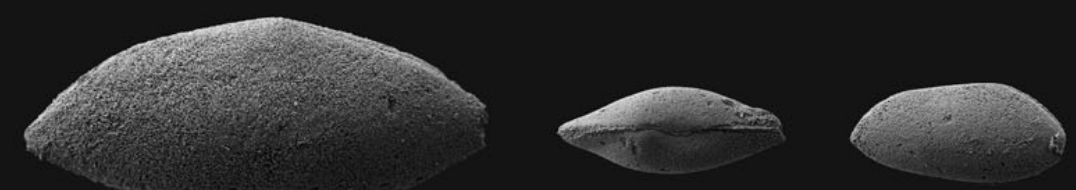

F

G
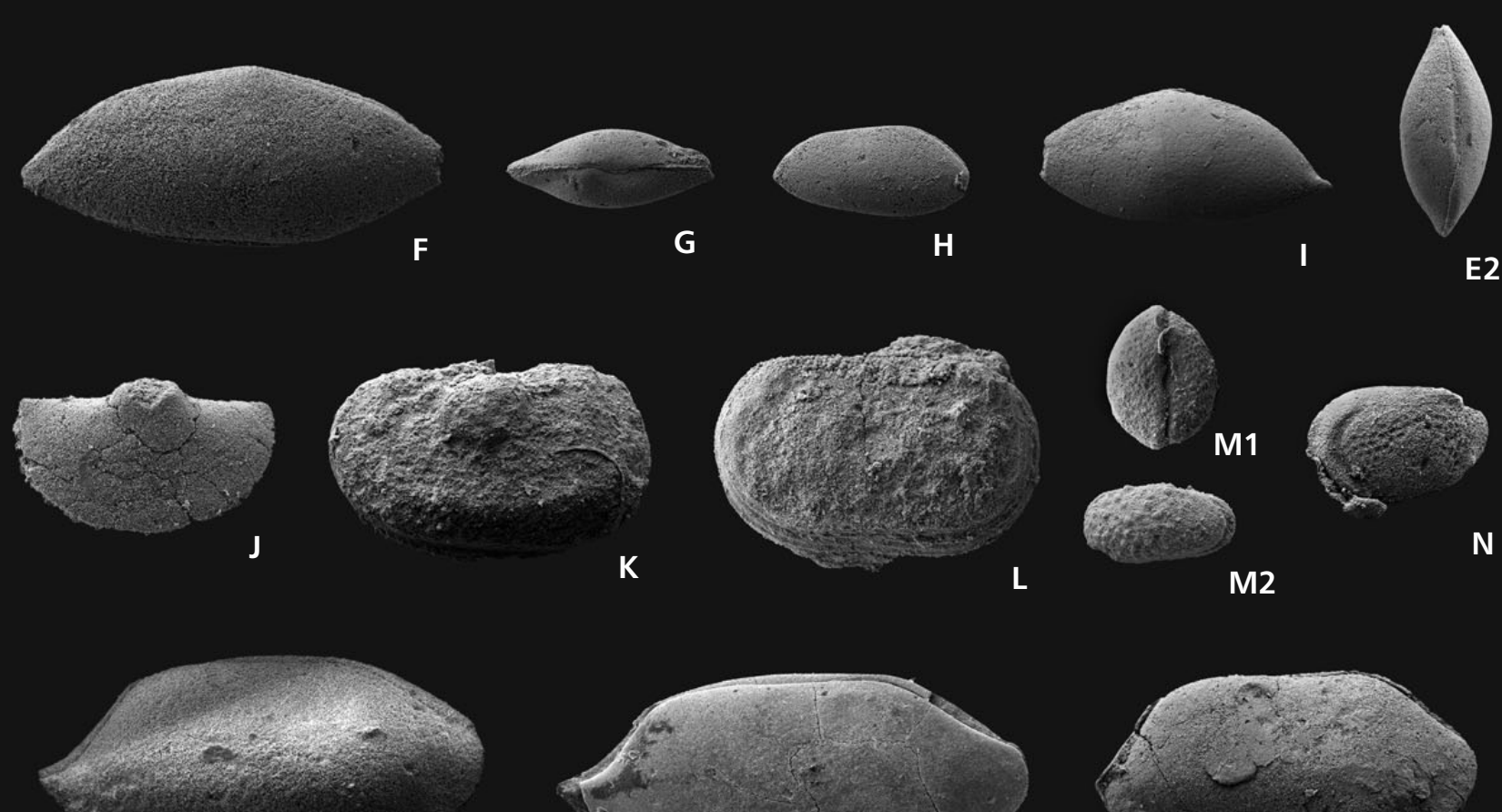

0
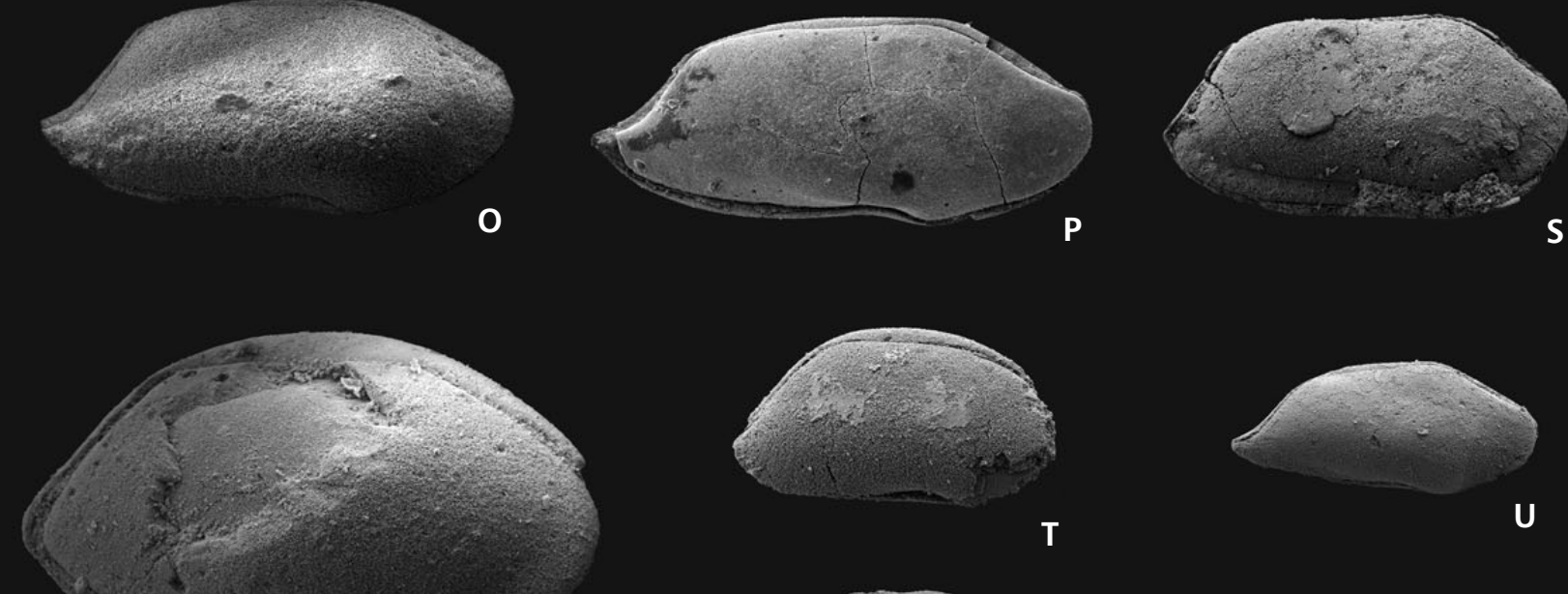

Q
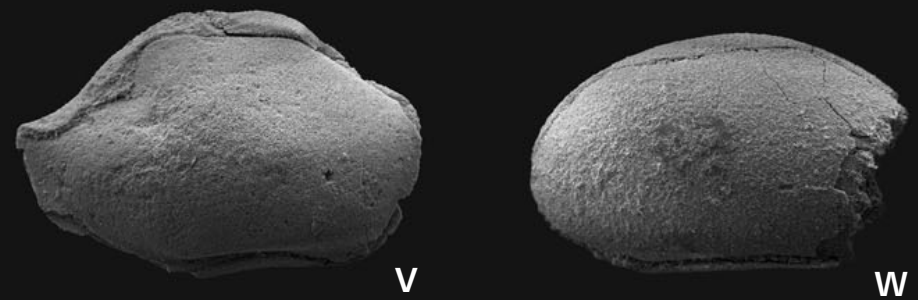

R
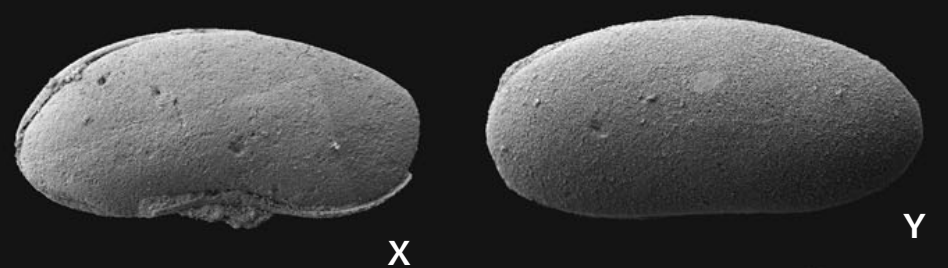
Origin of name. - Cristae: from "cristae", plural of crista (crest), alluding to the carapace ornamentation.

Diagnosis. - A questionable Orthocypris? with a smooth and suboval carapace and with a crista on the right valve running from the mid-dorsal to the posterodorsal area; right valves of adults sometimes with a second crista in the posteroventral area.

Description. - Ostracod with left valve slightly larger than right valve and with slight ventral overlap; smooth regular suboval carapace in lateral, dorsal and ventral views; $\mathrm{L} / \mathrm{H}$ ratio about 1.5 to $1.8, \mathrm{~L} / \mathrm{W}$ ratio about 1.8 ; maximal height located at mid-length; maximal length located at midheight; right valve with a crista extending from a middorsal to a posterodorsal area, particularly pronounced in juveniles; some right valves of adults with a second smaller crista running from the lower part of the mid-posterior area to the posteroventral area; in dorsal and ventral views, anterior and posterior margins form a regular circle bow; slightly bow-shaped projection of the left valve along the line of closure.

Remarks. - The assignment of the species to the genus Orthocypris is not without doubt, as the carapace is not very elongated. However, some other species of the genus such as O. cicatricosa Coen, 1985 share this feature.

The smaller crista on the right valve of adults can be interpreted either as sexual dimorphism or as ecomorphotypic ornamentation, but more specimens are necessary to test these hypotheses.

Comparison. - O.? cristae sp. nov. is similar only to $O$. $\mathrm{ci}$ catricosa Coen, 1985 (Middle Givetian, Ardennes), which has also one crista, but orientated differently. Besides that, O.? cristae differs from all others species of Orthocypris through its two cristae and by a less elongate carapace.
Occurence. - O.? cristae is present in the Ardennes in the upper part of the Mont d'Haurs Fm. and in the Fromelennes Fm. (Flohimont and Fort Hulobiet Mbs), and in the Boulonnais in the Blacourt Fm. (Couderousse Mb). O.? cristae ranges from the upper part of the lower $P$. varcus $(P$. rhenanus) to the $K$. disparilis zones of the standard conodont biozonation.

\section{Stratigraphical distribution}

The stratigraphical distribution of ostracods in the top of the Mont d'Haurs Fm. and in the Fromelennes Fm. shows two faunal intervals with distinctly different ostracod associations, both of which have high diversities (Fig. 11) (see below for a detailed description). The first one is found mainly in the deposits of the Middle Givetian Flohimont Mb. and the second one in the deposits of the Late Givetian Fort Hulobiet Mb. (Fig. 11). Inbetween these two intervals, the ostracods fauna has a low diversity and specimens are generally very rare, except for the top of the Moulin Boreux Mb. where several levels provided abundant Cryptophyllus sp. 3 sensu Magne, 1964. The two faunal intervals of high diversity correspond to the two major transgressive pulses in the Middle and the Late Givetian of the Givet area. The phase inbetween with low diversities and low numbers of individuals starts with a regressive pulse in the upper part of the Flohimont (Hubert \& Pinte 2009, Maillet \& Milhau 2010).

Therefore, this succession may be interpreted as phases of installation, stabilization and renewal of ostracod faunas during a major transgression-regression cycle as described by the sigmoid ranging concept of Devonian ostracods from platform sediments of Lethiers (1983a). The long time interval before the renewal of the fauna in the Late Givetian corresponds to sedimentary disturbances due to the Taghanic Biocrisis, during which fast alternations of T/R cycles resulted in very unstable environments (Préat \& Carliez 1994; Boulvain \& Coen-Aubert 1997;

Figure 5. Ostracods from the Fromelennes area. For explanation of the abbreviations and the bed numbering see the caption of Fig. 4. - A - Bairdiocypris vastus Polenova, 1952, CHL, 92' 'bs, MH, rv, C.O.U.L. 526. • B - Bairdiocypris cf. symmetrica (Kummerow, 1953), CHL, 101' 'st, MH, rv, C.O.U.L. 52. • C - Balantoides brauni (Becker, 1968), FLO, 112b, MH, 1v, C.O.U.L. 528. • D - Balantoides minimus (Lethiers, 1970), CHL, 176, FRfh, lv, C.O.U.L. 529. • E - Balantoides sp. A, FLO, 114, FRfl, rv, C.O.U.L. 530. • F - Baschkirina? sp. indet., FLO, $112 b$, MH, rv, C.O.U.L. 531. - G, H - Bufina aff. abbreviata Peterson, 1966; G - FLO, 114a, FRfl, rv, C.O.U.L. 532; H - FLO, 113a, MH, rv, juvenile, C.O.U.L. 533. • I - Bufina schaderthalensis Zagora, 1968, FLO, 125, FRfl, rv, juvenile, C.O.U.L. 534. • J - Cavellina devoniana Egorov, 1950, FLO, $113 c$, MH, lv, C.O.U.L. 53. - K - Cavellina rhenana Krömmelbein, 1954, CHL, 181, FRfh, 1v, female, C.O.U.L. 536. • L - Cavellina cf. macella Kummerow, 1953, CHL, 111' a, FRfl, lv, C.O.U.L. 537. • M - Cavellina sp. II sensu Groos, 1969, FLO, 122, FRf1, lv, C.O.U.L. 538. • N - Coeloenellina minima (Kummerow, 1953), CHL, 85', MH, lv, C.O.U.L. 539. • O - Coryellina cybaea (Rozhdestvenskaya, 1959), FLO, MH, 108a, rv, C.O.U.L. 540. • P - Coryellina cf. curta (Rozhdestvenskaya, 1959), Flo, 112b, MH, lv, C.O.U.L. 541.•Q - Coryellina? sp. A, FLO, 106, MH, rv, C.O.U.L. 542.・ R - Coryellina? sp. B, CHL, 178, FRfh, rv, C.O.U.L. 543. • S - Cryptophyllus aff. materni Bassler \& Kellet, 1934, FLO, 89', NSpa, rv?, C.O.U.L. 544. • T - Cryptophyllus sp. 3 sensu Magne, 1964, FLO, 146, FRmb, lv?, C.O.U.L. 545. • U - Cryptophyllus sp. G sensu Magne, 1964, FLO, 113a, MH, rv?, C.O.U.L. 546. - V - Cryptophyllus sp. B, CHL, 92'’a, MH, rv?, C.O.U.L. 547. • W - Cytherellina obliqua (Kummerow, 1953), FLO, 121, FRfl, rv, C.O.U.L. 548. - X - Cytherellina cf. groosae Coen, 1985, CHL, 109' 'b, FRfl, rv, C.O.U.L. 549. • Y - Cytherellina cf. perlonga (Kummerow, 1953), CHL, 101', MH, rv, C.O.U.L. 550. Z Z-Eridoconcha? cf. granulifera (Adamczak, 1961), FLO, 126, FRfl, lv?, C.O.U.L. 551. • AA - Eridoconcha? sp. A, FLO, 104c, MH, $1 v$ ?, C.O.U.L. 552. 


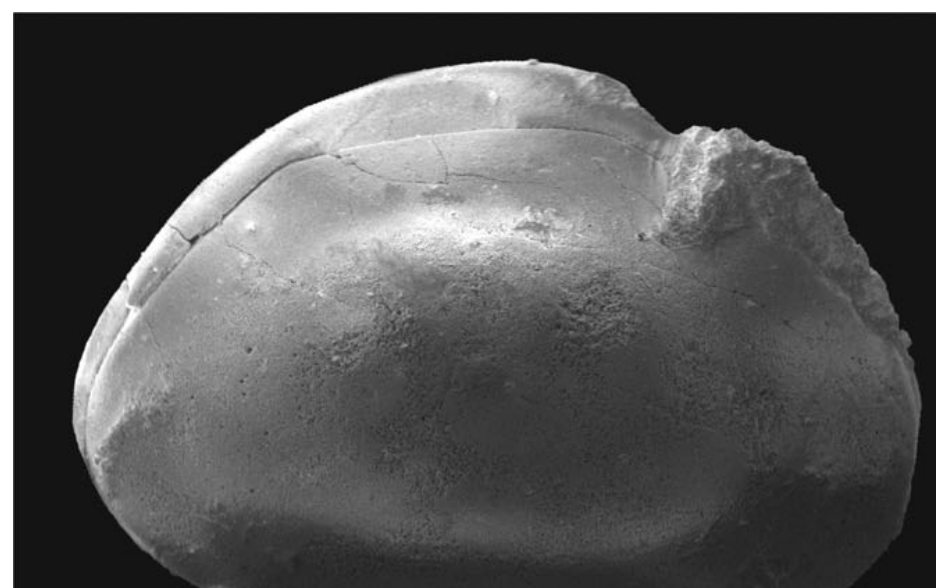

A
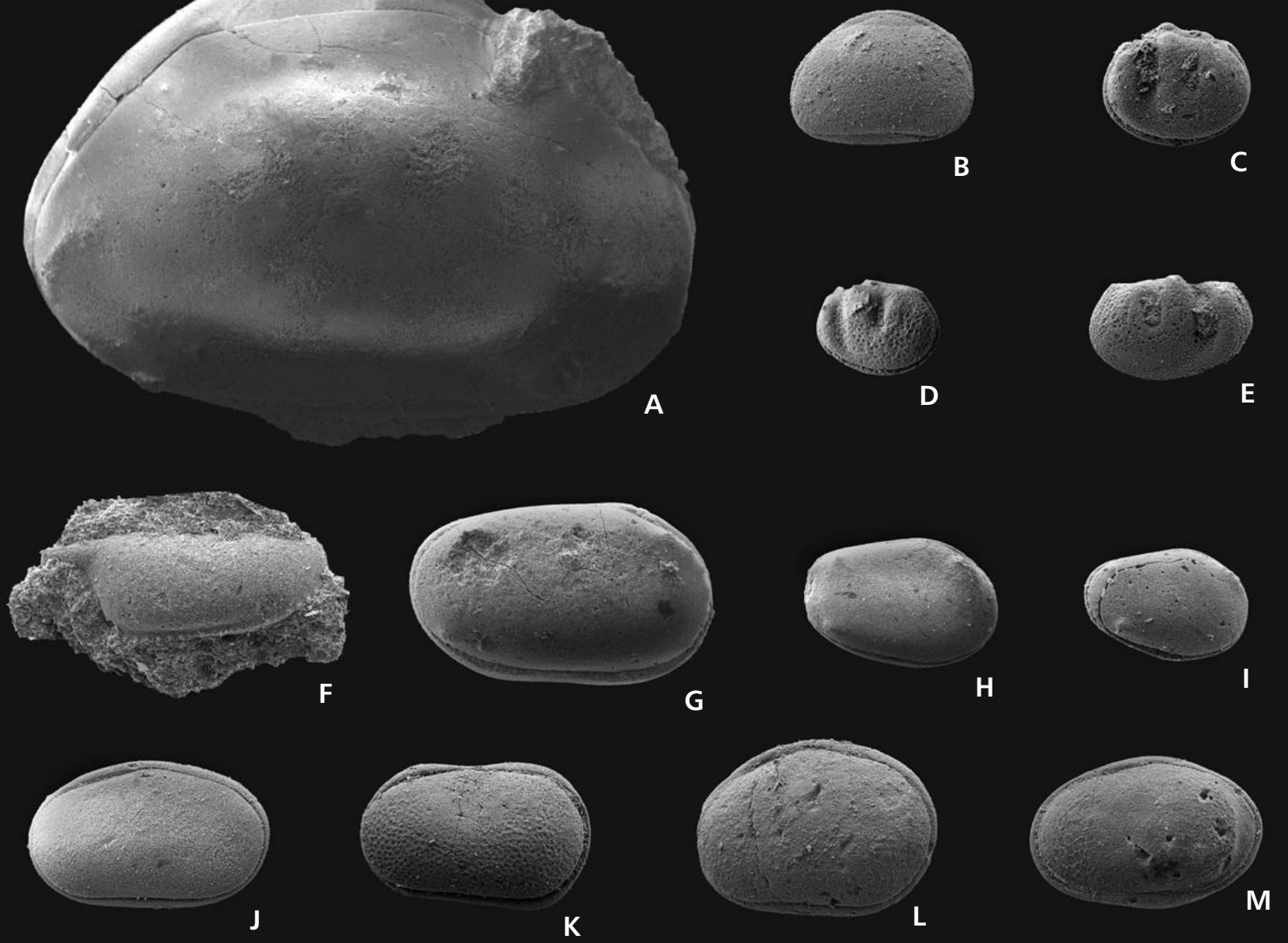

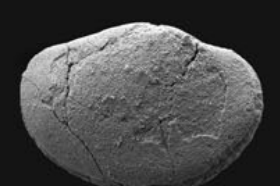

N

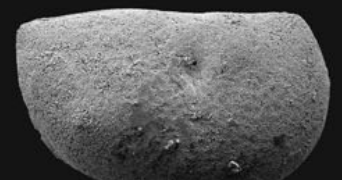

0
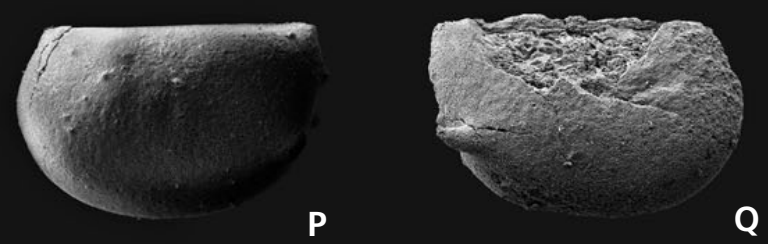

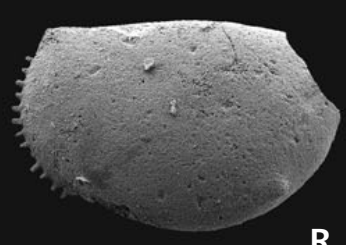

R
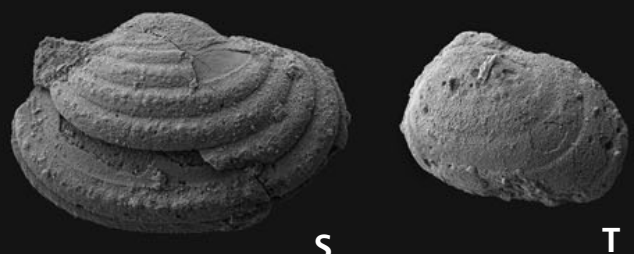

T
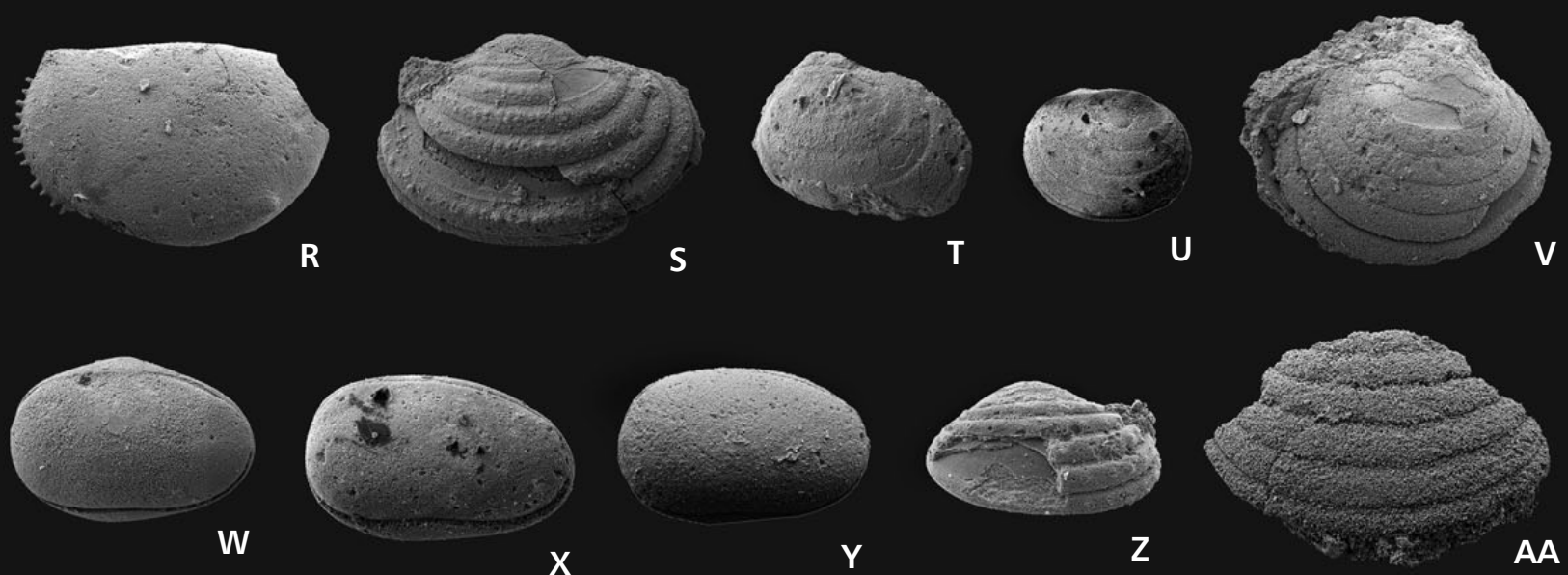
Coen-Aubert 2004; Pinte \& Mistiaen 2009, 2010; Maillet \& Milhau 2010; Brice et al. 2012). Regarding the lithology, the thickness and duration of the series is $140 \mathrm{~m}$, encompassing Middle and Late Givetian (see Fig. 3) and therefore 3,5 to $4 \mathrm{Ma}$ (Becker et al. 2012). The sedimentation rate does not vary significantly and can therefore be neglected as a factor influencing the diversity of the Fromelennes ostracods. A forthcoming publication will include analyzes and interpretation of the ostracod biodiversity pattern on the entire Givetian platform as regards global extinctions and regional to supraregional refuge areas during the Givetian bioevents.

The first of the two distinct ostracod faunas occurs from the top of the Mont d'Haurs Fm. almost up to the top of the Flohimont $\mathrm{Mb}$. and therefore corresponds to the first major trangsressive phase in the Givetian of the Ardennes. The faunal succession starts with a low diversity assemblage, which corresponds to the assemblage 1 of Milhau (1983a). Common species are benthic shallow water taxa belonging to the Eridostraca and Podocopina, with abundant Coeloenellina minima (Kummerow, 1953), Bairdiocypris vastus Polenova, 1952, Bairdia paffrathensis Kummerow, 1953 and Microcheilinella cf. amaliae Kummerow, 1953.

This first assemblage is then partly replaced and completed by species of the assemblage 2 of Milhau (ibid.), including Palaeocopina, Metacopina and Platycopina. Quasillites fromelennensis Milhau, 1983, Poloniella tertia Krömmelbein, 1953, Balantoides brauni (Becker, 1968), Bufina aff. abbreviata Peterson, 1966, Jenningsina heddebauti Milhau, 1983 and Cavellina devoniana Egorov, 1950 are the dominant species of this assemblage. The fauna is still a shallow water benthic community with taxa endemic to the Givetian platform, but the occurrence of many Metacopina associated with comparatively few thick-shelled Podocopina indicates an increase of the waterdepth. This deepening is also shown by the increase of ostracod diversity just above the first ten meters of the studied series, from about 20 to more than 65 taxa (Fig. 11). Of these, 48 are already known in the Ardennes from the earliest Givetian onward, but most of them do not appear in the Mont d'Haurs Fm. because of perireefal environments with too shallow waterdepths. A sedimentation pattern with more argillaceous input and a general diversification of macro- and microfaunas of open marine environments (e.g. Hubert \& Pinte 2009; Maillet et al. 2010, 2011) confirms the deepening. In the terms of Lethiers' (1983a) ranging concept this increase in ostracod diversity can be interpreted as phase 1a: the installation of fauna A during the beginning of a transgression. This first phase is characterized by short ranging taxa such as Ampuloides sp. 1 sensu Milhau, 1983 or Tubulibairdia sp. A. Locally short ranging taxa in the sections are e.g. Coelonellina minima (Kummerow, 1953) or Bairdia cf. siliklensis Rozhdestvenskaya, 1962, but they are known from the earliest Givetian of the Ardennes onward and occur, due to the transgressive-regressive sequences, periodically in the series (see Casier $e t$ al. 2010b, 2011a, 2011b, 2013).

In the first half of the subsequent Flohimont Mb. only a few additional ostracod taxa appear. The fauna now matches entirely with the assemblage 2 of Milhau (1983a) and still contains typical Givetian species, such as Quasillites fromelennensis Milhau, 1983, Coryellina cybaea (Rozhdestvenskaya, 1959), Bufina schaderthalensis Zagora, 1968, Kielciella arduennensis Adamczak \& Coen, 1992, Balantoides brauni (Becker, 1968), Poloniella tertia Krömmelbein, 1953, Parabolbinella coeni Casier, 2011 or Jenningsina heddebauti Milhau, 1983. Moreover, most of these taxa are endemic to the Givetian carbonate platform and show relatively long stratigraphical ranges.

We interpret this period as phase 2a of Lethiers' ranging concept: the phase of stabilization, which took place during the maximum transgression and is characterised by high diversities and long ranging ostracod taxa. However, no sedimentological evidence for this maximum has been

Figure 6. Ostracods from the Fromelennes area. For explanation of the abbreviations and the bed numbering see the caption of Fig. 4. - A, B - Euglyphella europaea Coen, 1985; A - CHL, 166, FRfh, lv, juvenile, C.O.U.L. 553; B - FLO, 87', FRfh, rv, C.O.U.L. 554. • C - Evlanella germanica Becker, 1964, CHL, 167, FRfh, rv, C.O.U.L. 555. • D - Evlanella sulcellina Becker, 1964, FLO, 58, FRfh, rv, C.O.U.L. 556. - E - Fabalicypris? sp. A, FLO, 63', FRfh, 1v, C.O.U.L. 557. • F - Fellerites sp. A, FLO, 113b, MH, C.O.U.L. 558. • G1 - Gravia schallreuteri (Becker, 1970b), FLO, 108b, MH, lv; G2 - DV, C.O.U.L. 559. • H - Gravia? sp. A, FLO, 112b, MH, rv, C.O.U.L. 560. • I - Healdianella sp. A, FLO, 90', NSpa, rv, C.O.U.L. 561. • J - Jefina cf. romei Coen, 1985, FLO, 113b, MH, 1v, C.O.U.L. 562.・K - Jenningsina catenulata (Van Pelt, 1933), FLO, 115, FRfl, 1v, C.O.U.L. 563. • L - Jenningsina heddebauti Milhau, 1983, FLO, 126, FRfl, 1v, C.O.U.L. 564. • M - Jenningsina paffrathensis Krömmelbein, 1954, FLO, 88', FRfh, rv, C.O.U.L. 565. • N - Kielciella arduennensis Adamczak \& Coen, 1992, FLO, 113, MH, lv, male, C.O.U.L. 566. • O - Kozlowskiella boloniensis Milhau, 1983, CHL, 109'’h, FRfl, rv, C.O.U.L. 567. • P, Q - Kozlowskiella plana (Kummerow, 1953); P - CHL, 189, FRfh, lv, C.O.U.L. 568; Q - Kozlowskiella plana (Kummerow, 1953), CHL, 189, FRfh, nested right valves, C.O.U.L. 569. • R - Kozlowskiella? sp. A, CHL, 109' 'h, FRfl, rv?, C.O.U.L. 570. • S - Knoxiella sp. 1 sensu Milhau, 1983, FLO, 112a, MH, rv, C.O.U.L. 571. • T, U - Macrocypris? sp. A, T-FLO, 60', FRfh, rv?, C.O.U.L. 572; U - FLO, 129, FRfl, rv?, C.O.U.L. 573. • V1 - Microcheilinella aff. ventrosa Polenova, 1960, CHL, 91', MH, VV; V2 - rv, C.O.U.L. 574. • W - Microcheilinella aff. amaliae Kummerow, 1953, CHL, 92' 'bs, MH, VV, C.O.U.L. 575. • X - Microcheilinella cf. clava (Kegel, 1932), CHL, 55/56, FRmb, DV, C.O.U.L. 576. • Y1 - Microcheilinella sp. B, FLO, 85', FRfh, VV; Y2 - 1v, C.O.U.L. 577. -Z-Microcheilinella sp. sensu Coen, 1985, FLO, 88', FRfh, rv, C.O.U.L. 578. • AA - Microcheilinella sp. B sensu Casier \& Préat, 1991, CHL, 178, FRfh, rv, C.O.U.L. 579. • AB - Nodella faceta Rozhdestvenskaya, 1972, CHL, 182, FRfh, lv, female, C.O.U.L. 580. • AC - Nodella hamata Becker, 1968, FLO, 89', NSpa, rv, C.O.U.L. 581. 

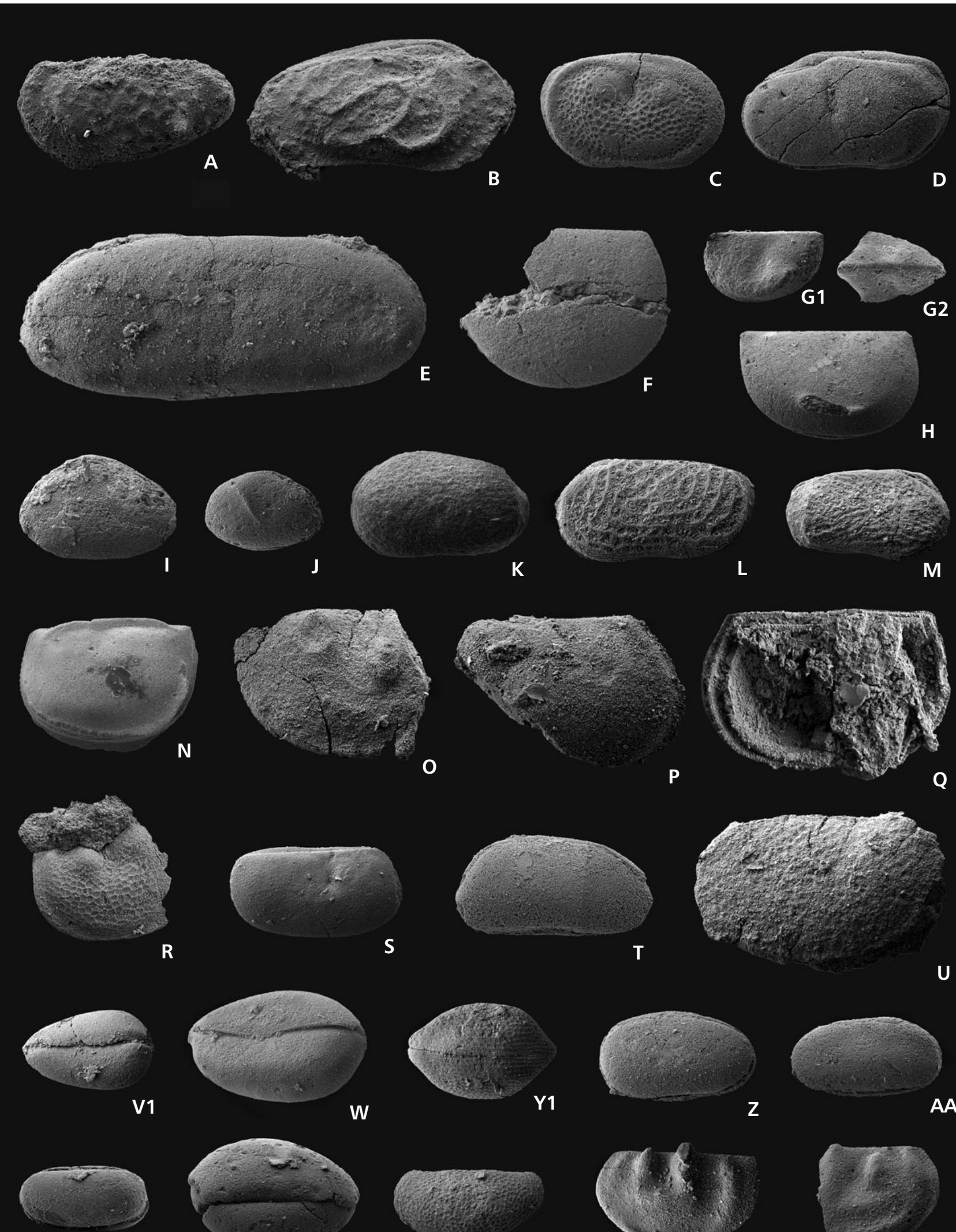

V2
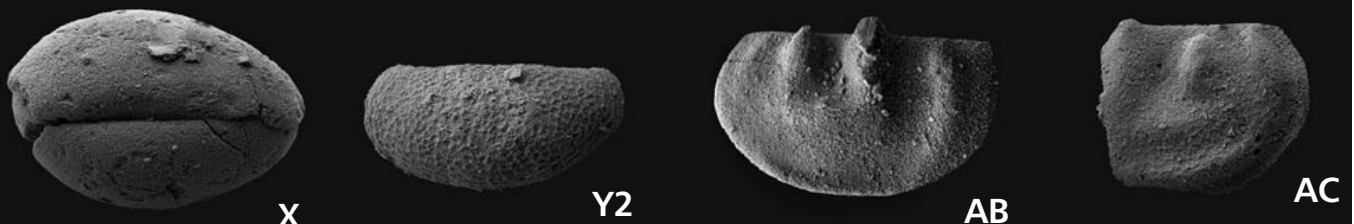
found in the lithology and it is not described in the literature to our knowledge. Regarding this fact and the general ostracod composition, which is not suspected to change much within a neritic shelf area below wave base, we assume that the deepening on the carbonate platform was only moderate.

In the upper part of the Flohimont Mb., the number of ostracod taxa significantly decreases, especially among the shallow water ostracods from the inner platform (Fig. 11). Some beds yielded a few Platycopina characteristic of semi-restricted environments (Eifelian assemblage I sensu Casier 2008) dominated e.g. by abundant Cavellina devoniana Egorov, 1950 and Evlanella germanica Becker, 1964; some beds are barren in ostracods. Due to its ostracod content, this part is interpreted as the phase $3 \mathrm{a}$ of Lethiers (1983a): the phase of extinction of fauna A, with a decrease of diversity due to a marine regression. The lithology of brachiopod-rich argillaceous limestones (Préat et al. 2006) reflects the regression only slightly with shaly intervals at the top of the Flohimont Mb., but the full extent of it is not seen lithologically before the Moulin Boreux $\mathrm{Mb}$. with biostromal and massive cryptalgal limestones. However, the assumption of a regression beginning in the top of the Flohimont $\mathrm{Mb}$. is corroborated by very abundant gastropods of semi-restricted environment and algae (indicating very shallow water) whereas other macro- and microfaunas are rarer and have a low diversity (Maillet et al. 2010).

The topmost Flohimont $\mathrm{Mb}$. and the subsequent strata of the entire Moulin Boreux Mb. are almost barren of ostracods as the area was situated in a semi-restricted back-reef environment (Préat \& Carliez 1994). Other faunal elements except algae, rugose corals and stromatoporoids (Hubert \& Pinte 2009, Maillet et al. 2011) are also rare, too. The rare and always badly preserved ostracods of the Moulin Boreux $\mathrm{Mb}$. are bairdiids and microcheilinellids, which are typical of fore-reef agitated environments (e.g. Becker 1971a, Casier 2008) and which are therefore allochthonous; no ostracods characterizing a back-reef facies have been found. Autochthonous faunas of semi-restricted environments occur only at the top of the Flohimont Mb. (see above) and in the uppermost part of the Moulin Boreux Mb. and consist of extremely rich but monospecific faunas of Cryptophyllus sp. 3 sensu Magne, 1964. In the Moulin Boreux Mb. they occur just before the onset of the characteristic Frasnian faunas. Similar accumulations are reported from the Blacourt Fm. in the Boulonnais (Magne 1964, Brice et al. 1976, Milhau 1988, Brice et al. 2012) and also from the base of the Famennian in Sinsin in the Ardennes (Casier \& Devleeshouwer 1995). Consequently, Cryptophyllus sp. 3 can be considered as an opportunistic and pioneer species in disturbed environments.

The long absence of ostracods is not in correspondence with the ranging concept of Lethiers (1983a), which suggests the installation of a new fauna B immediately after the extinction of the fauna $\mathrm{A}$ (phase $3 \mathrm{a}$ ), thus starting a new cycle (phase 1b). But the concept is based on undisturbed successions whereas in the sections studied herein, the consequences of the Taghanic Biocrisis, such as sea-level oscillations from back-reef to sebkha facies with some emersion phases, coupled with an increase of turbidity and salinity fluctuations (see Préat \& Carliez 1994; Boulvain \& Coen-Aubert 1997; Coen-Aubert 2004; Boulvain et al. 2009; Pinte \& Mistiaen 2009, 2010; Maillet \& Milhau 2010) hindered the installation of a new fauna. Moreover, numerous endemic species of the Givetian inner platform disappear around the Middle/Late Givetian boundary. More than $80 \%$ of the typical Givetian species have not been found in the younger strata of these sections, a phenomenon also known from the Boulonnais.

Not until the Fort Hulobiet Mb. does the progressive recovery and installation of a new ostracod fauna (phase $1 \mathrm{~b}$

Figure 7. Ostracods from the Fromelennes area. For explanation of the abbreviations and the bed numbering see the caption of Fig. 4. - A-G-Orthocypris? cristae sp. nov.; A1 - holotype, FLO, 130, FRfl, rv; A2 - DV, C.O.U.L. 582; B - paratype, CHL, 109' 'b, FRfl, rv, C.O.U.L. 583; C - CHL, 102”'a, FRfl, rv, C.O.U.L. 584; D - paratype, FLO, 126, FRfl, rv, C.O.U.L. 585; E - paratype, FLO, 130, FRfl, VV, C.O.U.L. 586; F- paratype, FLO, 130, FRfl, rv, C.O.U.L. 587; G - paratype, FLO, 130, FRfl, DV, C.O.U.L. 588. • H - Orthocypris cf. kummerowi Żbikowska, 1983, FLO, 89', NSpa, rv, C.O.U.L. 589. $\bullet$ I - Orthocypris cicatricosa Coen, 1985, FLO, 113b, MH, rv, C.O.U.L. 590. $\bullet$ J - Ovatoquasillites cf. nismesensis Casier in Casier \& Préat, 2009, FLO, 58’, FRfh, lv, C.O.U.L. 591 • K - Parapribylites hanaicus Pokorný, 1951, FLO, 130, FRfl, rv, C.O.U.L. 592. - L - Parapribylites cf. costatus (Glebovskaya \& Zaspelova, 1959), FLO, 111, MH, lv, C.O.U.L. 593. • M, N - Parabolbinella coeni Casier, 2011; M - FLO, 129, FRfl, rv, juvenile, C.O.U.L. 594; N - FLO, 125, FRfl, 1v, C.O.U.L. 595. • O - Plagionephrodes laqueus praelaqueus Casier \& Olempska, 2008, FLO, 88', FRfh, lv, C.O.U.L. 596. • P-R - Poloniella tertia Krömmelbein, 1953; P - FLO, 113b, MH, 1v, female, C.O.U.L. 597; Q - FLO, 126, FRfl, rv, juvenile, C.O.U.L. 598; R - CHL, 99', MH, DV, juvenile, C.O.U.L. 599. • S - Poloniella claviformis (Kummerow, 1953), FLO, 113b, MH, lv, C.O.U.L. 600. • T - Polyzygia beckmanni antecedens Zagora, 1968, FLO, 88', FRfh, 1v, C.O.U.L. 601. • U, V - Polyzygia beckmanni beckmanni Krömmelbein, 1954; U -FLO, 90', NSpa, rv, elongated morph, C.O.U.L. 602; V - FLO, 90', NSpa, rv, stocky morph, C.O.U.L. 603. -W - Polyzygia neodevonica Matern, 1929, FLO, 90', NSpa, lv, C.O.U.L. 604. - X-AB - Quasillites fromelennensis Milhau, 1983; X - FLO, 114a, FRfl, rv, juvenile, C.O.U.L. 605; Y - FLO, 114b, MH, rv, male, C.O.U.L. 606; Z - FLO, 107, MH, rv, male, C.O.U.L. 607; AA - FLO, 113b, MH, DV, female, C.O.U.L. 608; AB - 1983, FLO, 113b, MH, VV, female, C.O.U.L. 609. • AC - Quasillites? sp. A, CHL, 109''h, FRfl, rv, C.O.U.L. 610. AD - Quasillites lecomptei Coen, 1985, FLO, 119st, FRfl, rv, C.O.U.L. 611. • AE - Quasillites cf. fromelennensis Milhau, 1983, FLO, 40', FRfh, 1v, C.O.U.L. 612. • AF - Rectella trapezoides Zaspelova, 1959, FLO, 57’, FRfh, rv, C.O.U.L. 613. • AG - Refrathella struvei Becker, 1967, FLO, 130, FRfl, lv, C.O.U.L. 614. 


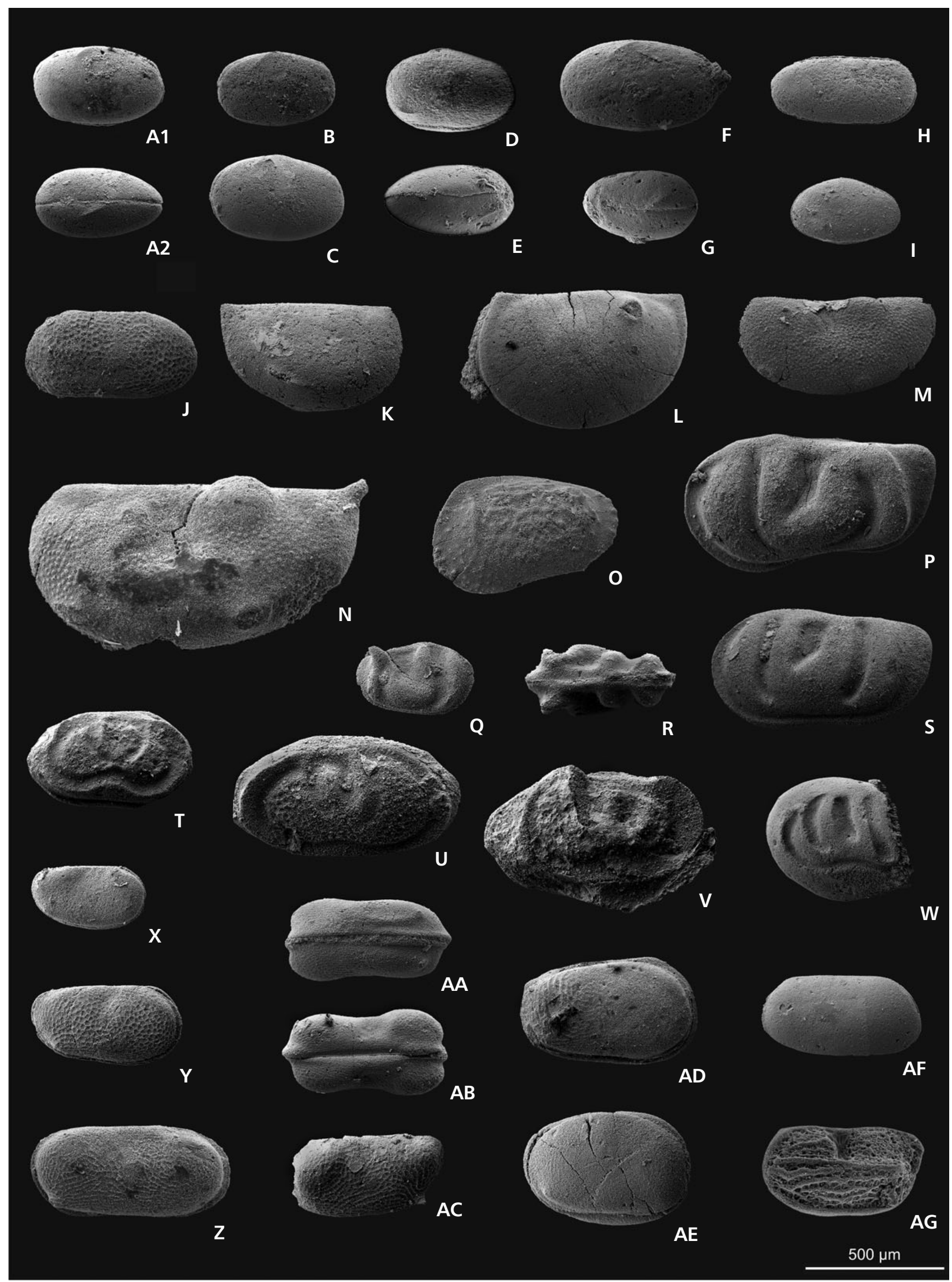




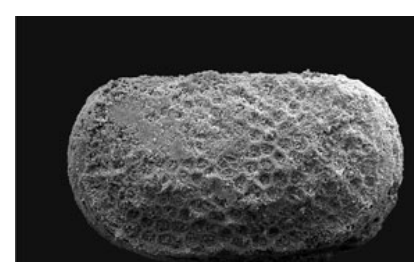

A

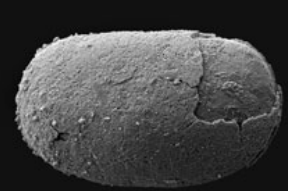

B

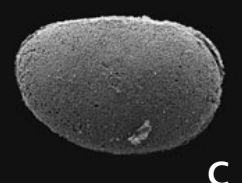

C

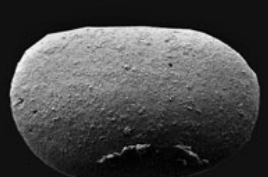

D

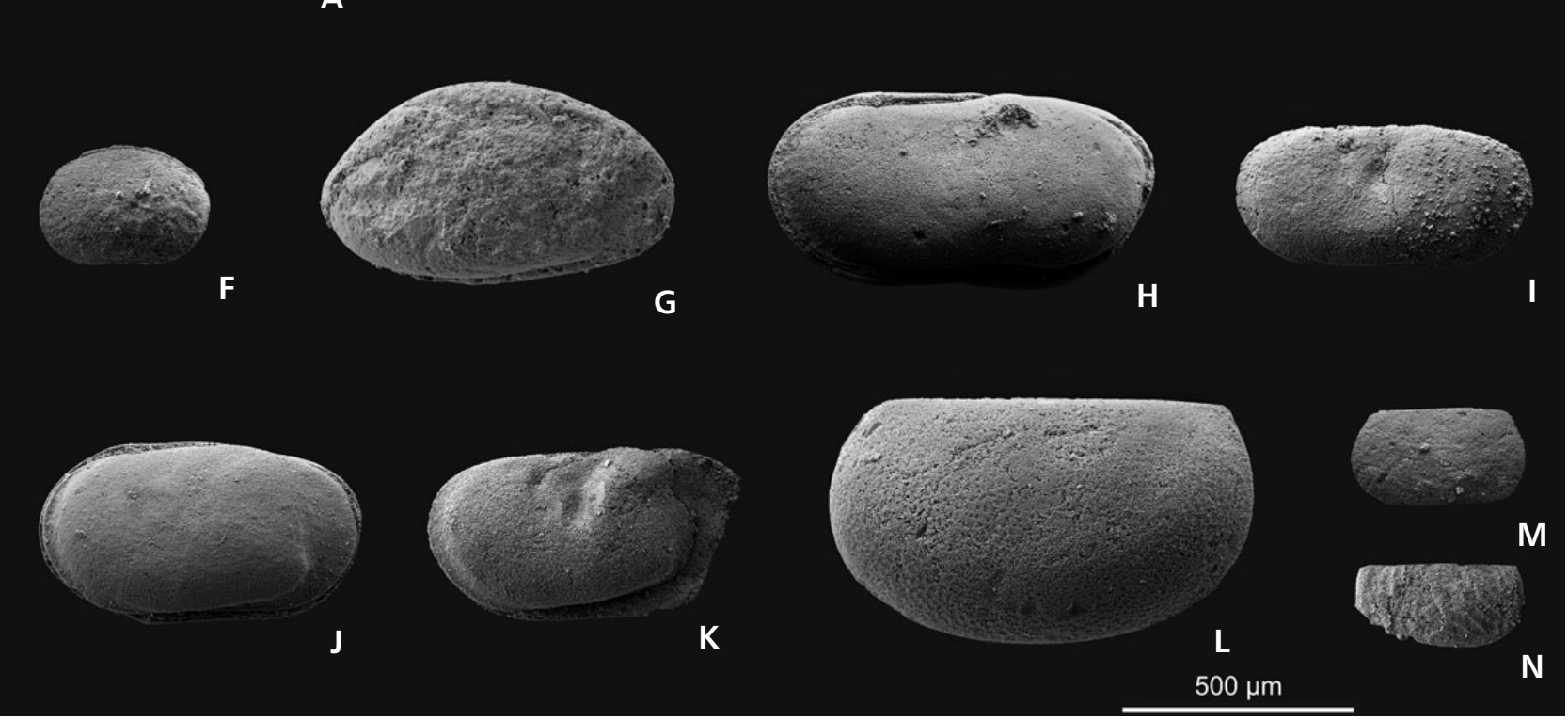

Figure 8. Ostracods from the Fromelennes area. For explanation of the abbreviations and the bed numbering see the caption of Fig. 4. $\bullet$ A - Roundyella patagiata (Becker, 1964), FLO, 49’, FRfh, 1v, C.O.U.L. 615. • B - Roundyella? sp. A, CHL, 209, FRfh, rv?, C.O.U.L. 616. • C - Samarella cf. laevinodosa Becker, 1964, FLO, 113b, MH, lv, C.O.U.L. 617. • D - Scrobicula gracilis Casier \& Olempska, 2008, FLO, 88', FRfh, lv, C.O.U.L. 618. -E - Semibolbina? sp. A, CHL, 215, FRfh, fragment, C.O.U.L. 619. • F - Silenites? sp. A, CHL, 101", MH, rv, C.O.U.L. 620. • G - Tubulibairdia sp. A, CHL, 100", MH, rv, C.O.U.L. 621. • H - Uchtovia abundans Pokorný, 1951, FLO, 56', FRfh, lv, male, C.O.U.L. 622. • I - Uchtovia materni Becker, 1971, FLO, 89', NSpa, rv, C.O.U.L. 623. • J - Uchtovia refrathensis (Krömmelbein, 1954), FLO, 40', FRfh, lv, C.O.U.L. 624. • K - Uchtovia? sp. A, FLO, 115, FRfl, rv, C.O.U.L. 625. • L - Urftella cf. adamczaki Becker, 1970b, FLO, 124, FRfl, lv?, C.O.U.L. 626. • M - Youngiella sp. A, FLO, 105, MH, rv, C.O.U.L. 627. • N - Youngiella sp. 5 sensu Magne, 1964, FLO, 78’, FRfh, rv, C.O.U.L. 628.

of Lethiers 1983a) take place, indicating the major transgression close to the Givetian/Frasnian boundary. After the long regressive phase with disturbed environments and the extinction of many endemic benthic ostracods, cosmopolitan species immigrate and recolonize the new habitats. As at the top of the Moulin Boreux Mb. with Cryptophyllus sp. 3, some beds at the base of the Fort Hulobiet Mb. are dominated by Cavellina rhenana Krömmelbein, 1954, suggesting the environment remains semi-restricted and quite unstable. Higher in the Fort Hulobiet Mb., the taxa already have a Frasnian character, such as Plagionephrodes laqueus praelaqueus Casier \& Olempska, 2008, Nodella faceta Rozhdestvenskaya, 1972, Jenningsina paffrathensis Krömmelbein, 1954, Uchtovia refrathensis (Krömmelbein, 1954), Euglyphella europaea Coen, 1985, Balantoides minimus (Lethiers, 1970) and Cryptophyllus aff. materni Bassler \& Kellett, 1934. The ostracod fauna corresponds to the third assemblage of Milhau (1983a). The occurrence of the geographically widespread Polyzygia beckmanni beckmanni Krömmelbein, 1954 confirms an age close to the Givetian/Frasnian boundary.

\section{Stratigraphical markers}

Four ostracod taxa of the Fromelennes Fm. show regional stratigraphic value as regards other areas in the Ardennes (Lethiers 1974, 1984; Milhau 1983a, 1983b; Coen 1985; Casier 1987, 2008; Casier \& Préat 1991, 2006, 2009) as well as the nearby Boulonnais (Magne 1964; Milhau 1983a, b, 1988; Lethiers 1982) and Eifel Hills (Krömmelbein 1954):

- Orthocypris? cristae sp. nov. is considered as a preliminary stratigraphical marker for the Middle to Late Givetian of the Givetian carbonate platform, as it has a range from the lower $P$. varcus Zone (Middle Givetian) and $K$. disparilis Zone (Late Givetian) and is reported in three localities of the Ardennes: the Flohimont and $\mathrm{Cul}$ d'Houille sections (Milhau 1983b, this paper), the Burnot section (Maillet 2010) and in the Late Givetian Blacourt Fm. (Milhau 1983a, 1988) in the Boulonnais area.

- Kielciella arduennensis Adamczak \& Coen, 1992 is also a possible stratigraphical marker for the Middle and 


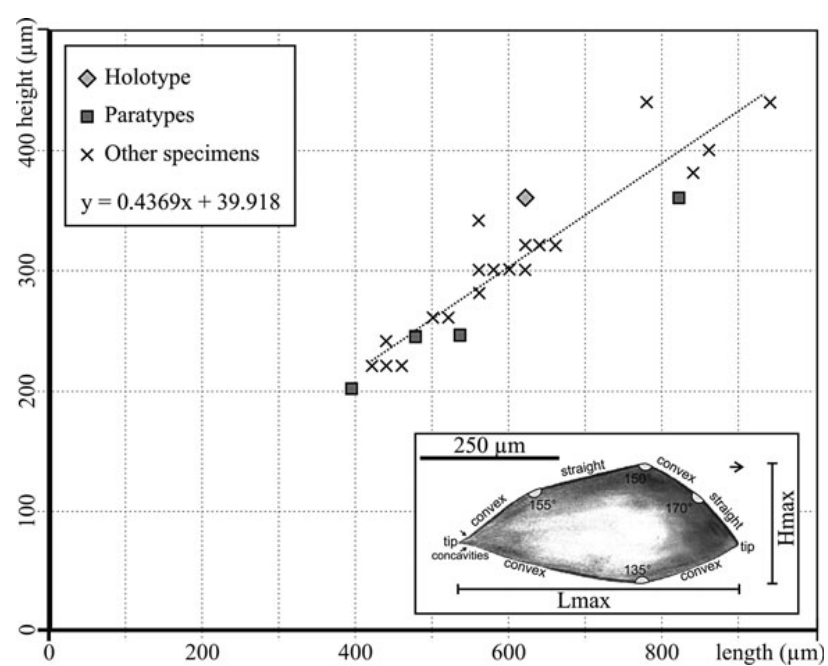

Figure 9. Height/length diagram for Acratia lucea sp. nov.

Late Givetian of the Ardennes area within the Givetian carbonate platform. It is reported so far from the Flohimont section (Adamczak \& Coen 1992, Coen 1985, this paper), the Cul d'Houille section (this paper) and the Burnot section (Maillet 2010).

- Jefina kaisini Coen, 1985 is known so far only from the Fromelennes Fm. (Coen 1985, this paper: Flohimont section and Cul d'Houille section) and is therefore considered as a preliminary stratigraphic marker in the region.

- Cavellina rhenana Krömmelbein, 1954 is a stratigraphical marker for the Late Givetian of the Rheno-Hercynian area with occurrences in the Boulonnais (Milhau 1988: top of the Blacourt Fm.), in the Eifel Hills (Krömmelbein 1954: upper Plattenkalk) and in the Ardennes (Milhau 1983a; Maillet 2010; Maillet et al. 2011, 2012; this paper: Fromelennes Fm., Fort Hulobiet Mb.).

Further studies on other sections are necessary to test the stratigraphical value of these species and to get more information on their local ranges.

\section{Faunal relations and palaeogeographic implications}

A comparison of the composition of the Givetian ostracods from the Fromelennes area with other Givetian ostracod records in Europe and northern Africa (Fig. 12) reflects distinctly the palaeogeography (Fig. 2). The faunal relationships with nearby areas on the Givetian platform (Préat \& Mamet 1989) are close and confirm a distinctive faunal province during the Givetian. Naturally the relationships of shallow water taxa become weaker with increasing distance from the Ardennes, as are the areas around the Laurussian continent, the European terranes and northern Peri-Gondwana. However, there are still some common

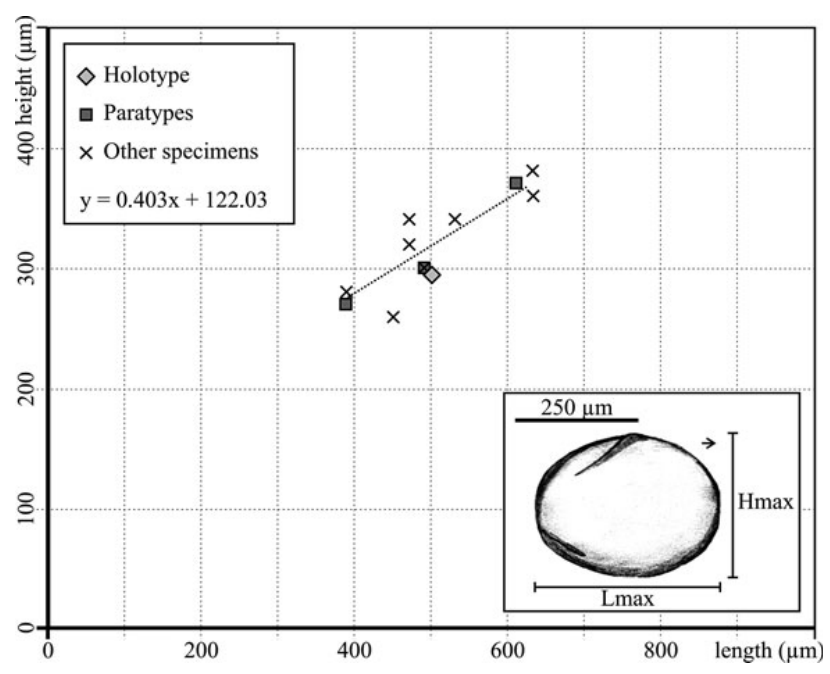

Figure 10. Height/length diagram for Orthocypris? cristae sp. nov.

species between all these regions (see below) showing the migration paths of benthic ostracods and, consequently, that the separating oceans must have been narrow and only moderately deep.

The closest faunal relations exist between the Ardennes and the Boulonnais (Ferques Massif) areas in France and the Eifel Hills, Bergisches Land and Sauerland areas in Germany (Fig. 12). This mirrors their close geographical positions in Givetian times on the same carbonate platform at the southern border of Laurussia (Fig. 2; Stampfli et al. 2002). These strong affinities between the Ardennes, the Boulonnais and the German Rhenish Slate Mountains have also been shown by Coen (1985). On a genus level, the Boulonnais shares about $72 \%$ (38/53 genera found in the Fromelennes area), and the German Rhenish Slate Mountains about $65 \%$ of the taxa (34/53 genera), with the Fromelennes area. On species level, the Boulonnais has the closest relations with about $43 \%$ (49/113 species) of common ostracods (Magne 1964; Lethiers 1970, 1982; Milhau 1983a, b, 1988; Coen 1985). The German Rhenish Slate Mountains shares about 38\% (43/113 species) of ostracod species (Kummerow 1953; Becker 1964, 1965a, b, 1967, 1968a, b, 1969, 1970, 1971a; Groos 1969) with the studied area (Fig. 12). Endemic taxa in the Rheno-Hercynian area such as Acratia lucea sp. nov., Balantoides brauni (Becker, 1968), Cavellina rhenana Krömmelbein, 1954, Cryptophyllus sp. 3 sensu Magne, 1964, Cytherellina obliqua (Kummerow, 1953), Euglyphella europaea Coen, 1985, Evlanella germanica Becker, 1964, Jenningsina heddebauti Milhau, 1983, Kozlowskiella boloniensis Milhau, 1983, Orthocypris cicatricosa Coen, 1985, Orthocypris? cristae sp. nov., Parabolbinella coeni Casier, 2011, Quasillites fromelennensis Milhau, 1983, Quasillites lecomptei Coen, 1985, Roundyella patagiata (Becker, 1964), Uchtovia materni 


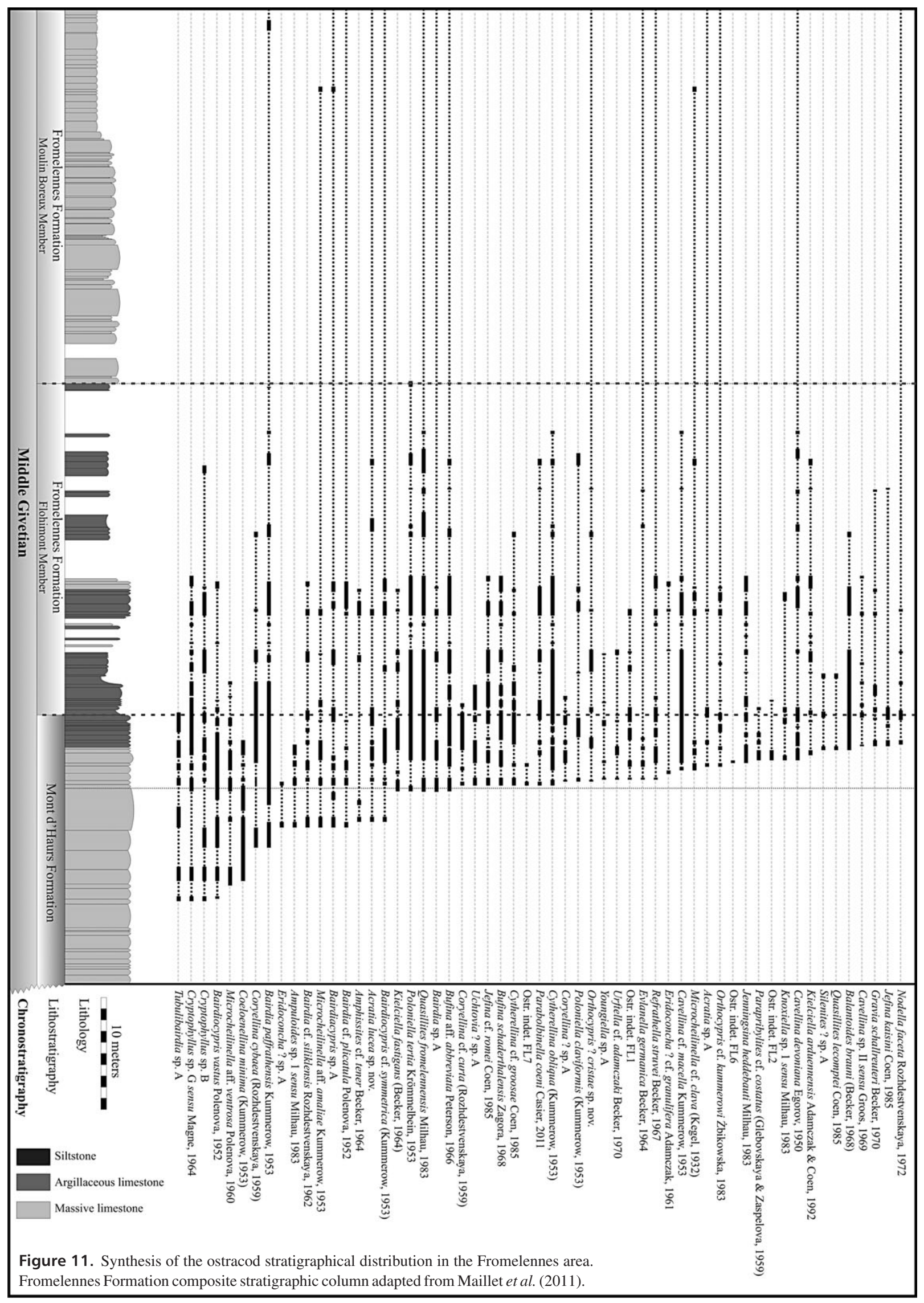




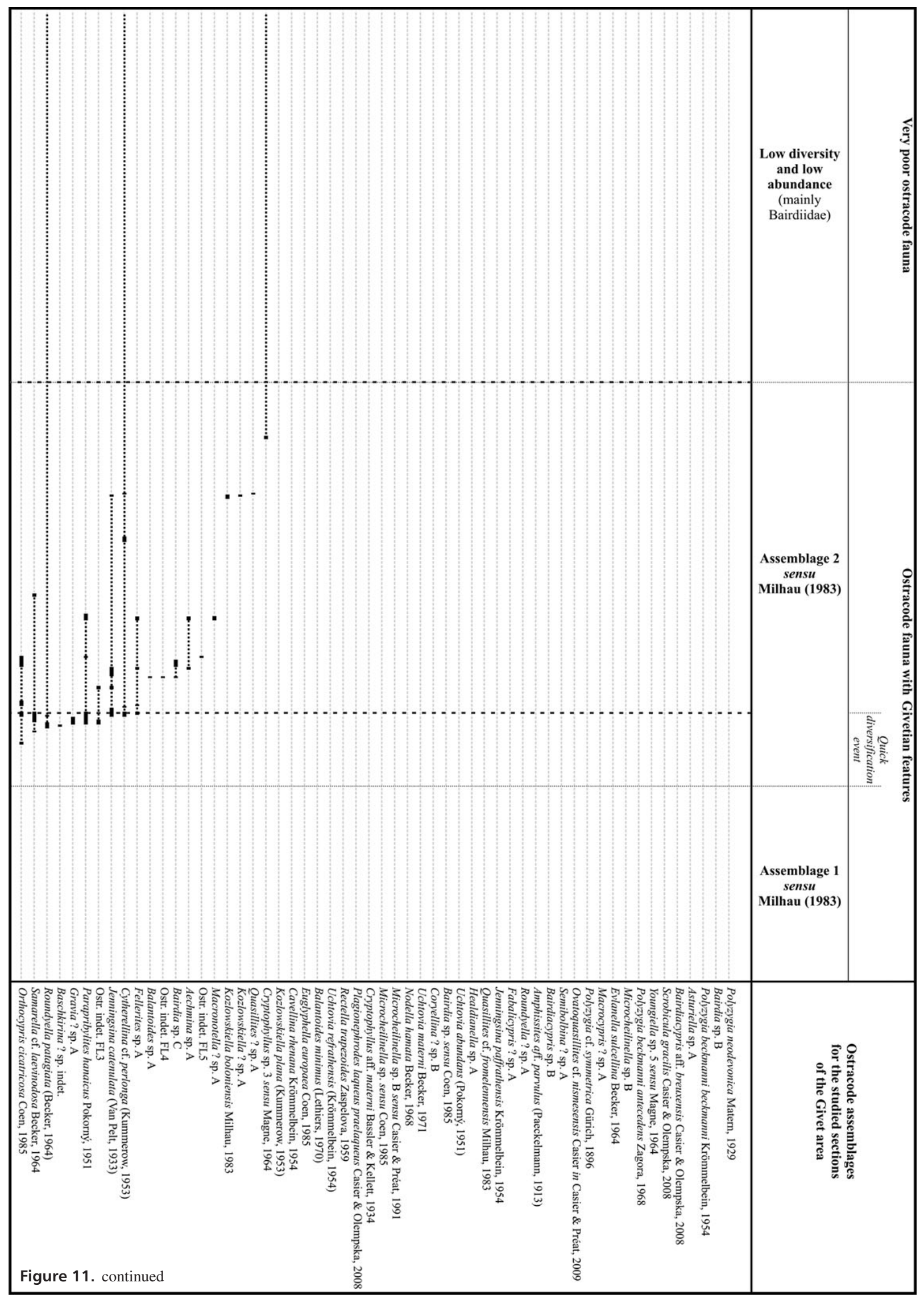




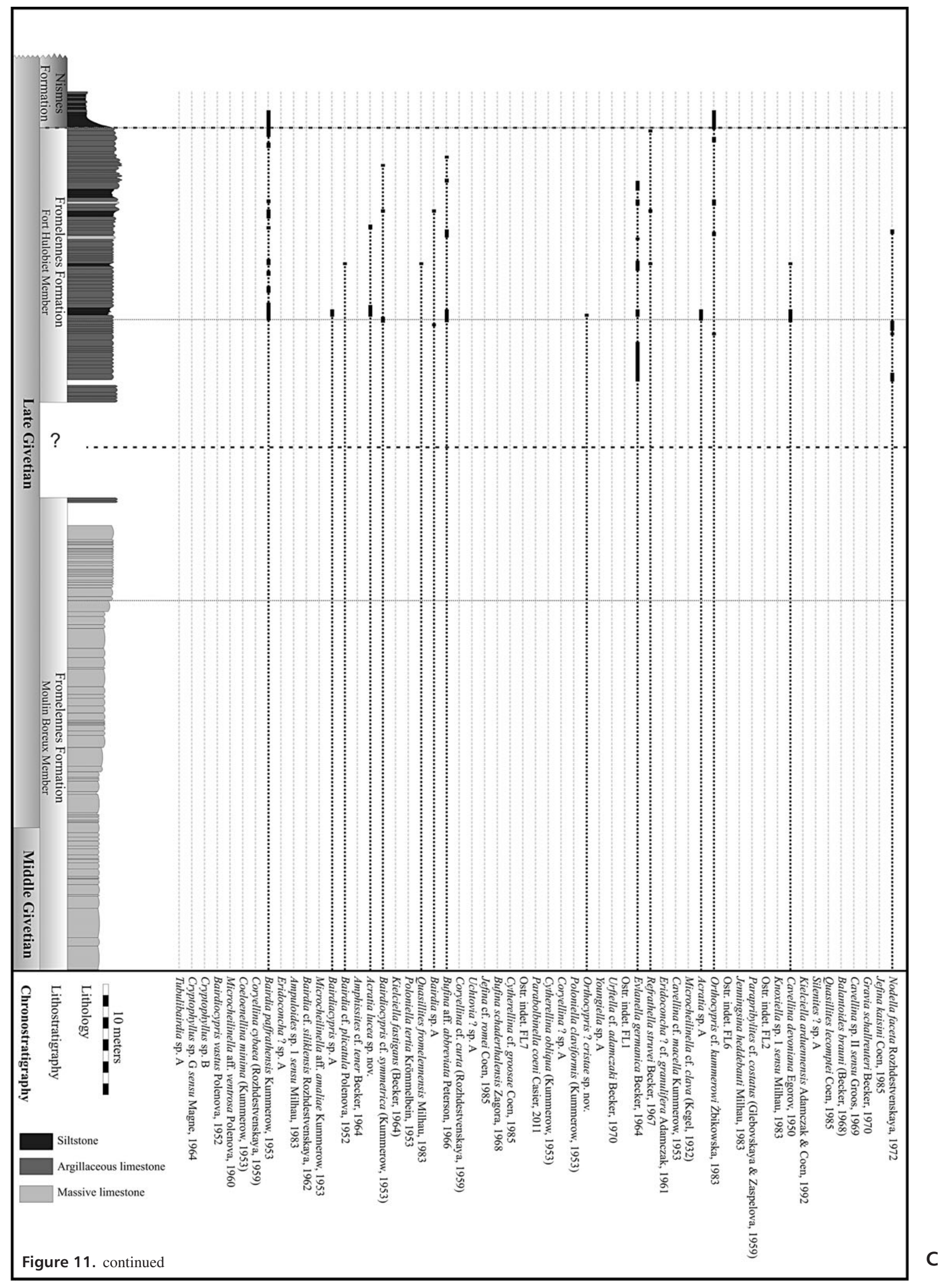




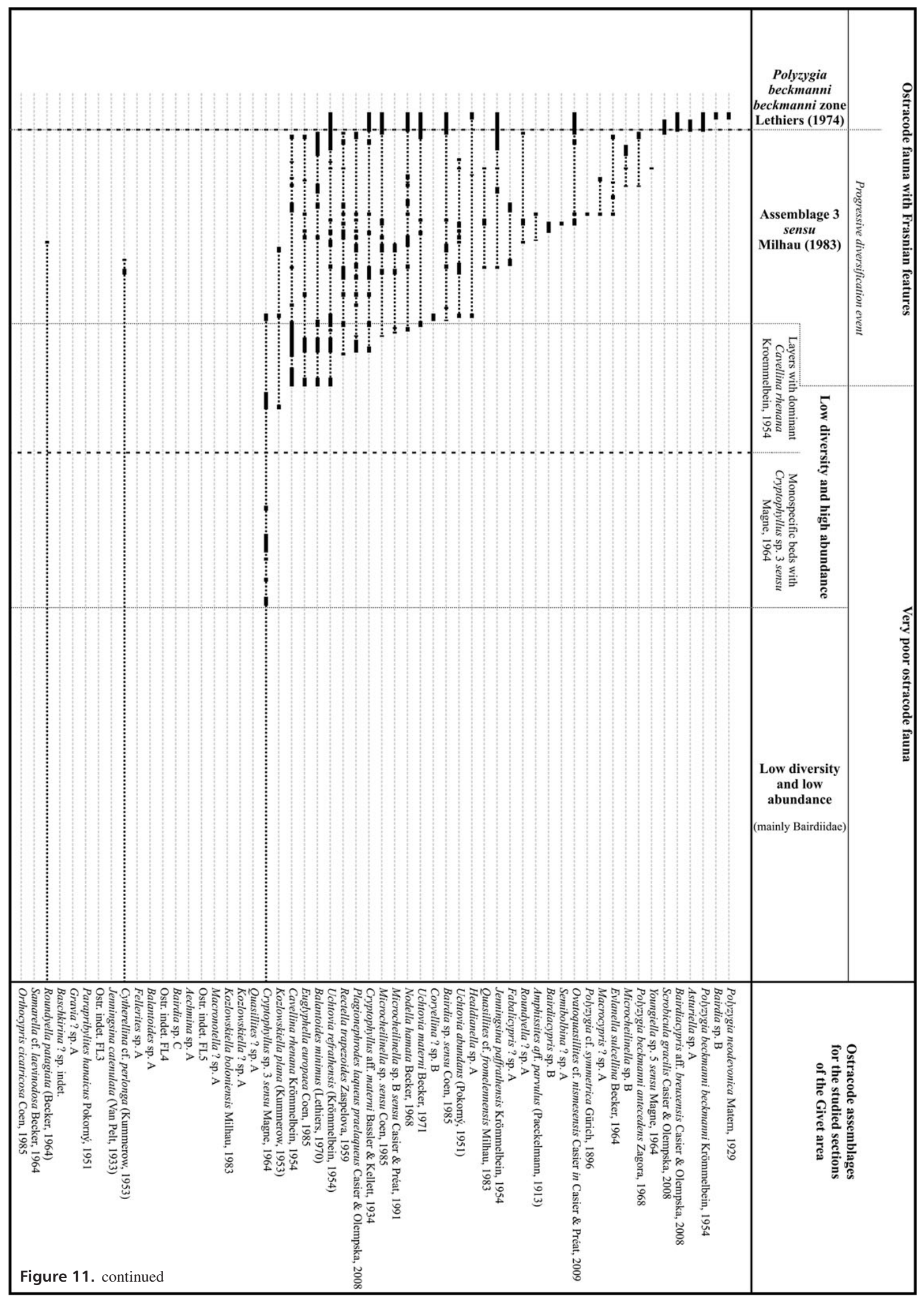

D 
Becker, 1971 or Urftella adamczaki Becker, 1970 corroborate the palaeogeographic proximity.

The ostracod fauna of the Holy Cross Mountains (Přibyl 1953; Adamczak 1968, 1976; Zagora 1968; Olempska 1979; Żbikowska 1983; Malec \& Racki 1993) shows also a close relation to the Ardennes with nearly $75 \%$ of shared genera, which corroborates the position of both areas on the same platform. On a species level, however, not even a quarter of the taxa occur in both regions, reflecting the long palaeogeographic distances between the areas (Fig. 2). Species only known from the Rhenish area and Poland are Samarella cf. laevinodosa Becker, 1964, Uchtovia abundans (Pokorný, 1951), Bufina schaderthalensis Zagora, 1968 or Coelonellina minima (Kummerow, 1953), whereas Bairdia paffrathensis Kummerow, 1953, Bairdiocypris vastus Polenova, 1952 or Cavellina devoniana Egorov, 1950 are more cosmopolitan.

Givetian ostracods described in the Volga and Ural areas in Russia (Egorov 1950, 1953; Polenova 1952, 1953, 1960; Zaspelova 1952, 1959; Rozhdestvenskaya 1959, 1962, 1972) show only a vague relationship with the Fromelennes area. Less than a quarter of taxa are shared at both genus and species levels (Fig. 12), which indicates the greater palaeogeographic distance to the Ardennes.

The European Terranes including the areas of Cantabria (Asturias, Leòn), the Armorican Massif, the Montagne Noire and the Mouthoumet Massif (France) were situated during the Givetian inbetween the large continents of Laurussia and Gondwana (Fig. 2; Stampfli et al. 2002). Due to the palaeoecological barriers, the faunal relationships of benthic ostracods are not very close but they still existed. By comparison with the other areas of the European Terranes, the ostracods of the Montagne Noire (Casier \& Préat 1996, 2007) show so far the closest relations to the Fromelennes area: about $34 \%$ of the genera are common in both areas, but only three species are shared (Fig. 12). As regards Asturias-Leòn, the Armorican Massif and the Mouthoumet Massif, the database is insufficient to compare the faunal inventory as only a few Givetian ostracods have been reported (Becker 1988, Bessière \& Lethiers 1985, Lethiers \& Racheboeuf 1993, Michel 1972, Milhau 1996).

Several Middle Devonian ostracods of Bohemia are described by Pokorný (1951), Přibyl (1951) and Šlechta (1996), but only 4 species and 13 genera are common with the studied area, and moreover these are widespread and long-ranging taxa within the Devonian. These vague relationships might either be the result of missing data or they could support the hypothesis of an independent Bohemian Terrane (Perunica; $c f$. Cocks \& Torsvic 2006).

Givetian ostracods from the shallow sea deposits around Gondwana are known from three localities: Milhau (1996) and Casier et al. (2010a) reported faunas from the Tafilalt (Morocco), Casier \& Préat (1997) studied faunas from the north-western Meseta in Morocco and Le Fèvre
(1963, 1971) as well as Casier $(1983,1985,1986)$ described ostracods from Ougarta (Algeria). The Tafilalt has about $38 \%$ of common genera with the Fromelennes area (20/53 genera found in the Fromelennes area are shared), but only Polyzygia beckmanni beckmanni Krömmelbein, 1954, Polyzygia neodevonica Matern, 1929, Polyzygia symmetrica Gürich, 1896, Jenningsina catenulata (Van Pelt, 1933) and Refrathella struvei Becker, 1967 are shared species. The north-western Meseta has about $50 \%$ of common genera (27/53 genera) with the Fromelennes area, but only $10 \%$ of common species $[11(+3$ ? $) / 113]$. The Ougarta area has about $26 \%$ of common genera (14/53 genera are shared) with the Fromelennes area and shares only Cytherellina cf. perlonga (Kummerow, 1953) and Polyzygia neodevonica Gürich, 1896 on a species level. But, the stratigraphically important species of Polyzygia corroborate the faunal exchange between the shallow marine areas of the Givetian platform in the south of Laurussia and the shelf areas of the north of Gondwana (see e.g. Michel 1972; Lethiers 1982, 1983b; Dojen et al. 2010).

\section{Discussion}

The composition of the ostracod faunas from the Fromelennes area shows major changes from the Middle to the Late Givetian, which are most probably closely related to the major transgressions and to the global Taghanic Biocrisis.

With the first Middle Givetian transgression from the top of the Mont d'Haurs Fm. to the beginning of the Flohimont Mb., a typical Givetian benthic ostracod fauna with many endemic species and with close relationships to other faunas on the Givetian platform is present. Many of these open-marine taxa of this Givetian fauna are known from the earliest Givetian and reappear at each transgressive pulse (e.g., Casier et al. 2010b, 2011a, b, 2013). Accordingly, the semi-restricted taxa of this Givetian fauna reappear during the regressive phases until the beginning of the Taghanic Biocrisis.

Due to the Taghanic Biocrisis which is related to stressful environments of rapid sea-level oscillations, turbidity and salinity variations, many Givetian taxa of the inner platform (especially endemic ones) disappear. Many species $(80 \%)$ have their last occurrence at least within the Rheno-Hercynian zone, probably even globally. By contrast, euhaline and open-marine generalists belonging to the Bairdiidae (Casier 1987, 2008), some opportunistic Platycopina and also some Metacopina living in deeper environments (ibid.), persist until the latest Givetian. However, the strata of the Moulin Boreux Mb. (late Middle Givetian to earliest Late Givetian) are almost barren of ostracods. As for other marine faunas (e.g. May 1995, House 2002, Aboussalam 2003, Baird \& Brett 2008, Aboussalam \& Becker 2011) the Taghanic Biocrisis leads 


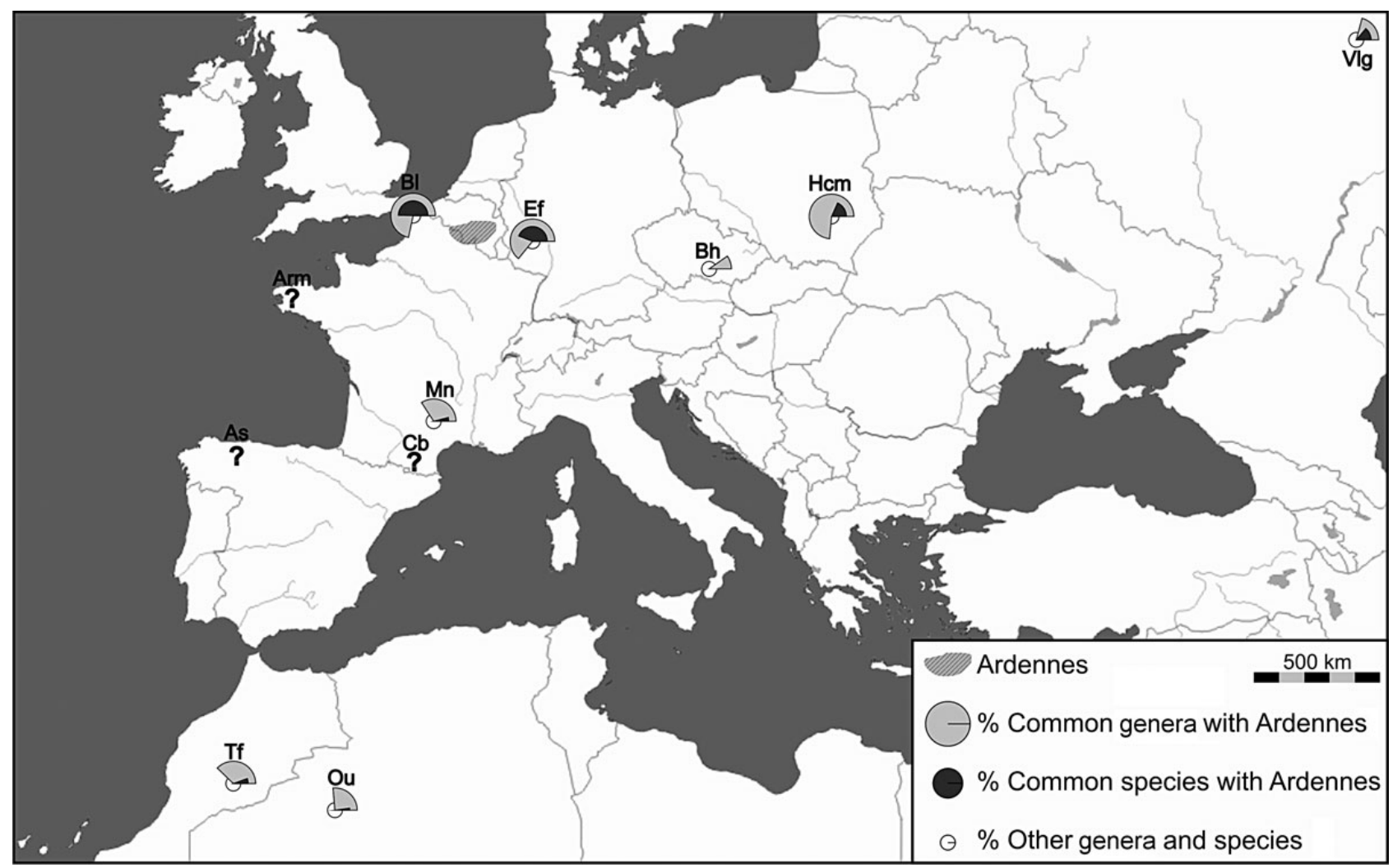

Figure 12. Faunal affinities with other places in Europe and northern Africa. Abbreviations: Arm - Armorican Massif; As - Asturias; Bh - Bohemian Massif; Bl - Boulonnais; Cb - Mouthoumet Massif; Ef - Eifel Hills, Sauerland and Bergisches Land; Hcm - Holy Cross Mountains; Mn - Montagne Noire; Ou - Ougarta; Tf - Tafilalt; Vlg - Volga-Ural.

to a reduction in provincialism among the benthic ostracod community. Due to the Givetian/Frasnian transgression and the subsequent drowning of the Givetian carbonate platform (Boulvain et al. 2009) the geographical barriers are removed and more cosmopolitan ostracod taxa can now immigrate in the Late Givetian (Lethiers 1983b). This new fauna shows Frasnian affinities as it yields only a few typical Givetian taxa but many ostracods which have their acme in the Frasnian, such as Polyzygia beckmanni beckmanni Krömmelbein, 1954, Polyzygia neodevonica Matern, 1929, Scrobicula gracilis Casier \& Olempska, 2008 and Uchtovia materni Becker, 1971. This change in the faunal composition is possibly amplified by the climate becoming more arid at the end of the Givetian (Marshall et al. 2011, Casier et al. 2013), which causes warmer water temperatures, an increase in continental erosion and therefore a higher detrital influx to the shelf (Boulvain et al. 2009).

Our own studies (unpublished) indicate that the disappearance of "Givetian" benthic ostracod faunas during the Middle and Late Givetian and their replacement by "Frasnian" faunas by the end of the Givetian can also be found in other sections of the Ardennes and in Algeria (Saoura). Moreover, the comparison of Devonian faunas described from the Boulonnais, Germany, Poland and Algeria also show a different composition of "Givetian" and "Frasnian" faunas. Due to insufficient data, it cannot be proven if the faunal replacement commenced by the Late Givetian in all these areas. But, it can be said due to the correlation of dating and palaeogeography it is most likely a supraregional or even a global phenomenon linked to the Taghanic Biocrisis and the Givetian-Frasnian sea level rise.

\section{Conclusions}

The composition of the benthic ostracod faunas from the Ardennes significantly changed in the period between the Middle and the Late Givetian. This change is most probably a consequence of the global Taghanic Biocrisis and of the sea level rise close to the Givetian/Frasnian boundary, which caused the disappearance of the endemic Givetian fauna during the Middle and Late Givetian and its replacement by a more cosmopolitan fauna with Frasnian affinities as early as the latest Givetian. The influence of the sea level rise is possibly amplified by the climate change at the end of the Givetian.

This pattern of disappearance in the Middle Givetian related to the Taghanic Biocrisis and the replacement of the 
fauna in the Late Givetian during the beginning of the Givetian/Frasnian boundary transgression is clearly a supraregional phenomenon. Detailed studies on other areas exposing the Middle/Late Givetian time period are needed to confirm a possible global pattern.

Orthocypris? cristae sp. nov. and Kielciella arduennensis Adamczak \& Coen, 1992 are considered as stratigraphical markers for the Middle to Late Givetian of the Givetian platform. Cavellina rhenana Krömmelbein, 1954 occurs only in the Late Givetian of the Rheno-Hercynian area and Jefina kaisini Coen, 1985 is a regional marker for the Fromelennes Fm.

A Middle/Late Givetian faunal province on the carbonate platform of the northern Rhenohercynian margin is confirmed by close relationships between the ostracod taxa from the Ardennes and those from the Boulonnais (France), the other areas of the Rhenish Massif (e.g. Eifel Hills in Germany) and the Holy Cross Mountains (Poland). Faunal interactions during the Givetian also exist between this platform, the European Terranes (e.g. Armorica, Iberia) and the northern margin of Gondwana, suggesting the existence of narrow oceans between these continents.

\section{Acknowledgments}

This paper is a contribution to IGCP 596 "Climate change and biodiversity patterns in the Mid-Palaeozoic". We appreciate the assistance of P. Deville (Laboratoire de Paléontologie Stratigraphique FLST/ISA, Lille) in the field and for hot acetolysis. We are also particularly grateful to J.-P. Nicollin (Laboratoire de Paléontologie Stratigraphique FLST/ISA, Lille) and to V. Perrier (University of Leicester) for their advice and help to improve the manuscript and to P. Recourt (Université Lille 1 Sciences et Technologies) for the ESEM micrographs. Thanks go to C.E. Bennett (University of Leicester) and A. Lord (Senckenberg Institute, Frankfurt) for their help to improve the English language of the manuscript. Thanks to the Institut Catholique de Lille for the financial support of this project. We also thank the Office National des Forêts (O.N.F.), the Conservatoire des Espaces Naturels de Champagne-Ardennes (C.E.N.C.A.) and the Ardennes prefecture for the sampling authorizations in the Pointe de Givet reserve, as well as the Fromelennes town council and the residents living near outcrops, and particularly $\mathrm{M}$. Vigneron, owner of the Nichet caves. Finally, we would like to thank J.-G. Casier (Institut Royal des Sciences Naturelles de Belgique, Bruxelles) and C. Klug (Paleontological Institute and Museum, University of Zurich, Switzerland) for reviewing the manuscript.

\section{References}

Aboussalam, S. 2003. Das 'Taghanic-Event' im höheren Mitteldevon von West-Europa und Marokko. Münstersche Forschungen zur Geologie und Paläontologie 97, 1-332.

Aboussalam, S. \& Becker, R.T. 2011. The Global Taghanic
Biocrisis (Givetian) in the eastern Anti-Atlas, Morocco. Palaeogeography, Palaeoclimatology, Palaeoecology 304, 136-164. DOI 10.1016/j.palaeo.2010.10.015

AdAMCZAK, F. 1961. Eridostraca - a new suborder of ostracods and its phylogenetic significance. Acta Palaeontologica Polonica 6, 47-64.

AdamczaK, F. 1968. Palaeocopa and Platycopa (Ostracoda) from Middle Devonian rocks in the Holy Cross Mountains, Poland. Acta Universitatis Stockholmiensis, Stockholm Contributions in Geology 17, 1-109.

AdamcZaK, F. 1976. Middle Devonian Podocopida (Ostracoda) from Poland: their morphology, systematics and occurrence. Senckenbergiana lethaea 57(4-6), 265-467.

AdAMCZAK, F. \& CoEn, M. 1992. Perimarginal and antral structures in some primitiopsides (Palaeocopina, Ostracoda). Neues Jahrbuch für Geologie und Paläontologie, Monatshefte 6, 321-335.

BAIRD, G.C. \& BRetT, C.E. 2008. Late Givetian Taghanic bioevents in New York State: New discoveries and questions. Bulletin of Geosciences 83(4), 357-370.

DOI 10.3140/bull.geosci.2008.04.357

Bassler, R.S. \& Kellett, B. 1934. Bibliographic Index of Paleozoic Ostracoda. Geological Society of America Special Papers 1, 1-500. DOI 10.1130/SPE1-p1

BeCKer, G. 1964. Palaeocopida (Ostracoda) aus dem Mitteldevon der Sötenicher Mulde (N-Eifel). Senckenbergiana lethaea 45, 43-113.

Becker, G. 1965a. Podocopida (Ostracoda) aus dem Mitteldevon der Sötenicher Mulde (N-Eifel). Senckenbergiana lethaea 46, 367-441.

BECKER, G. 1965b. Revision Kummerow'scher Ostracodenarten aus dem deutschen Mitteldevon. Fortschritte in der Geologie von Rheinland und Westfalen 9, 151-188.

BECKER, G. 1967. Refrathella n. gen. (Kirkbyellidae). Senckenbergiana lethaea 48(6), 511-523.

BECKER, G. 1968a. Geschlechtsdimorphismus bei Ostracoden, 2. Natur und Museum 98, 119-172.

BeCKer, G. 1968b. Ostracoda aus den Refrath-Schichten (Oberdevon) der Paffrather Mulde (Bergisches Land). 2: Zur Morphologie und Systematik der Palaeocopida Gattungen Nodella Zaspelova und Aechminella Harlton. Senckenbergiana lethaea 49, 547-563.

BeCKer, G. 1969. Ostracoda aus dem Mitteldevon der Sötenicher Mulde (N-Eifel). Biostratigraphie, Paleoökologie und taxonomische Bemerkungen. Senckenbergiana lethaea 50(2-3), 239-271.

Becker, G. 1970. Primitiopsacea (Ostracoda, Palaeocopida) aus dem Rheinischen Devon. Senckenbergiana lethaea 51(1), 49-65.

Becker, G. 1971a. Paleoecology of middle Devonian Ostracodes from the Eifel region, Germany, 801-816. In OeRTLI, H.J. (ed.) Colloque sur la Paléoécologie des Ostracodes, Pau, 20-27 juillet 1970. Bulletin du Centre de Recherche de Pau, SPNA 5 suppl.

BeCKer, G. 1971b. Ostracoda aus dem Mittel-Frasnium (Oberdevon) der Mulde von Dinant. Bulletin de l'Institut royal des Sciences naturelles de Belgique 47(34), 1-94.

BeCKer, G. 1988. Neritische Ostracoden aus der Huergas Formation des Kantabrischen Gebirges (Givetum; N-Spanien). Senckenbergiana lethaea 68(5-6), 393-431. 
Becker, G. 2001. Contributions to Palaeozoic Ostracod Classification [POC], No. 18. The Superfamily Bairdiacea Sars, 1888. 1. Family Bairdiidae Sars, 1888 (Palaeozoic members only). Neues Jahrbuch für Geologie und Paläontologie, Abhandlungen 220(2), 267-294.

Becker, R.T., Gradstein, F.M. \& Hammer, O. 2012. The Devonian Period, 559-601. In Gradstein, F., OGG, J., Schmitz, M. \& OGG, G. (eds) The Geologic Time Scale 2012, Volume 2.

Berdan, J.M. \& Sohn, I.G. 1961. Family Pachydomellidae Berdan \& Sohn, n. fam, Q373-Q374. In Moore, R.C. \& Pitrat, C.W. (eds) Treatise on Invertebrate Paleontology, Part $Q$, Arthropoda 3, Crustacea, Ostracoda. Geological Society of America \& University of Kansas Press, New York \& Lawrence.

Bessière, G. \& Lethiers, F. 1985. Le Paléozoique du Massif de Mouthoumet, 14-22. In Bilotte, M., Villatte, J., TamBAREAu, Y., Bessière, G., Babinot, J.-F. \& Lethiers, F. (eds) Journée d'étude des ostracodologistes de langue française dans les Hautes-Corbières. Bulletin de la Société d'Etudes Scientifiques de l'Aude 85.

Blakey, R.C. 2007. Devonian, north Atlantic region (400 Ma). Palaeobotanical research group, Dept. of Geology, Northern Arizona Univ., Flagstaff, University Münster. Available online: http://jan.ucc.nau.edu/rcb7/400NAt.jpg

Bless, M.J.M. \& JoRdAn, H. 1971. Classification of palaeocopid ostracodes belonging to the families Ctenoloculinidae, Hollinidae and Hollinellidae. Bulletin du Centre de Recherches Pau-SNPA 5, 869-890.

BouČEK, B. 1936. Die Ostracoden des Böhmischen Ludlows (Stufe e $\beta$ ). Neues Jahrbuch für Mineralogie, Geologie und Paläontologie 76(B), 31-98.

Boulvain, F. \& Coen-Aubert, M. 1997. Le sondage de Focant: lithostratigraphie et implications structurales. Memoirs of the Geological Survey of Belgium 43, 1-74.

Boulvain, F., Mabille, C., Poulain, G. \& Da Silva, A.- C. 2009. Towards a palaeogeographical and sequential framework for the Givetian of Belgium. Geologica Belgica 12(3-4), 161-178.

Brice, D., Bultynck, P., Colbeaux, J.-P., Lethiers, F., Mistiaen, B., Rohart, J.-C. \& Bigey, F. 1976. Une nouvelle coupe dans le Dévonien de Ferques (Boulonnais-France). Annales de la Société Géologique du Nord 96, 136-155.

Brice, D., Milhau, B., Mistiaen, B., Rohart, J.-C. \& Vidier, J.-P. 1989. Le Givétien supérieur (Dévonien) à Ferques (Boulonnais - France): Observations nouvelles. Annales de la Société Géologique du Nord 108(2/3), 113-123.

Brice, D. \& Mistiaen, B. 2008. Le stratotype du Givétien à Givet. Livret Guide de l'excursion de la Société Géologique du Nord, 8 mars 2008, Laboratoire de Paléontologie Stratigraphique FSTL-ISA \& Géosystèmes UMR 8157 CNRS, 1-18.

Brice, D., Pinte, E. \& Mistiaen, B. 2012. The global Taghanic Biocrisis (Givetian) on brachiopods of the Ferques inlier area (Boulonnais - France). Centenary Meeting of the Paläontologische Gesellschaft, Programme, Abstracts and Field Guide, 38.

Bultynck, P. 1974. Conodontes de la Formation de Fromelennes du Givétien de l'Ardenne Franco-Belge. Bulletin de l'Institut royal des Sciences naturelles de Belgique 12(31), 50/10, 1-30.

Bultynck, P., Casier, J.-G., Coen-Aubert, M. \& Godefroid, J. 2001. Préconférence field trip (V1): Couvin - Phillipeville Wellin area, Ardenne (May 11-12, 2001). The $15^{\text {th }}$ Interna- tional Senckenberg Conference, Joint Meeting IGCP 421/SDS, May 2001, Field Trips Guidebook, 1-44.

Bultynck, P., Coen-Aubert, M., Dejonghe, L., Godefroid, J., Hance, L., Lacroix, D., Préat, A., Stainier, P., Steemans, P., Streel, M. \& Tourneur, F. 1991. Les Formations du Dévonien Moyen de la Belgique. Mémoire pour servir à l'explication des cartes géologiques et minières de la Belgique, ministère des affaires économiques, administration des mines, service géologique de Belgique, Bruxelles, 30, 1-106.

Bultynck, P. \& Dejonghe, L. 2001. Devonian lithostratigraphic units (Belgium). Geologica Belgica 4(1-2), 39-69.

Caputo, M.V., Gonçalves Melo, J.H., Streel, M. \& Isbell, J.L. 2008. Late Devonian and Early Carboniferous glacial records of South America. The Geological Society of America Special Paper 441, 161-173.

Casier, J.-G. 1983. Les ostracodes du Frasnien et de la base du Famennien de la coupe du Km 30 (Saoura, Sahara algérien). Bulletin de la Société Belge de Géologie 91(4), 195-207.

CASIER, J.-G. 1985. Les ostracodes de la partie supérieure de la Formation de Teferguenite (Givétien) et de la Formation de Marhouma (Givétien-Famennien) de la coupe du km 30 (Saoura, Sahara algérien). Geobios 18(6), 833-846. DOI 10.1016/S0016-6995(85)80038-3

CASIER, J.-G. 1986. Les ostracodes de la partie supérieure de la Formation de Teferguenite: erratum. Geobios 19(2), 266.

CASIER, J.-G. 1987. Etude biostratigraphique et paléoécologique des ostracodes du sommet du Givétien et de la base du Frasnien à Ave-et-Auffe (Bord sud du bassin de Dinant, Belgique). Bulletin de la Société Belge de Géologie 96(1), 23-34.

CAsier, J.-G. 2008. ROLF 22, résumés des communications et guide de l'excursion consacrée aux ostracodes du Dévonien Moyen et Supérieur du Synclinorium de Dinant. 22e Réunion des Ostracodologistes de Langue Française, Institut Royal des Sciences Naturelles de Belgique, Département de Paléontologie, Bruxelles, 1-83.

Casier, J.-G., Cambier, G., Devleeschouwer, X., Petitclerc, E. \& PrÉAT, A. 2010b. Ostracods, rock facies and magnetic susceptibility of the Trois-Fontaines and Terres d'Haurs Formations (Early Givetian) in the Rancennes quarry at the Mont d'Haurs (Givet, France). Bulletin de l'Institut royal des Sciences naturelles de Belgique, Sciences de la Terre 80, 85-114.

Casier, J.-G. \& Devleeschouwer, X. 1995. Arguments (Ostracodes) pour une régression culminant à proximité de la limite Frasnien-Famennien, à Sinsin, bord sud du bassin de Dinant, Belgique. Bulletin de l'Institut royal des Sciences naturelles de Belgique, Sciences de la Terre 65, 51-68.

Casier, J.-G., Devleeschouwer, X., Maillet, S., Petitclerc, E. \& PRÉAt, A. 2013. Ostracods and rock facies across the Givetian/Frasnian boundary interval in the Sourd d'Ave section at Ave-et-Auffe (Dinant Synclinorium, Ardenne, Belgium). Bulletin of Geosciences 88(2), 241-264.

DOI 10.3140/bull.geosci.1340

Casier, J.-G., Devleeschouwer, X., Moreau, J., Petitclerc, E. \& PRÉAT, A. 2011b. Ostracods, rock facies and magnetic susceptibility records from the stratotype of the Terres d'Haurs Formation (Givetian) at the Mont d'Haurs (Givet, France). Bulletin de l'Institut royal des Sciences naturelles de Belgique, Sciences de la Terre 81, 97-128.

Casier, J.-G., Devleeschouwer, X., Petitclerc, E. \& Préat, A. 
2011a. Ostracods, rock facies and magnetic susceptibility of the Hanonet Formation and Trois-Fontaines Formation transition (Early Givetian) at the Mont d'Haurs (Givet, France). Bulletin de l'Institut royal des Sciences naturelles de Belgique, Sciences de la Terre 81, 63-96.

Casier, J.-G., El Hassani, A. \& Préat, A. 2010a. Ostracodes du Dévonien moyen et supérieur du Tafilalt (Maroc). Revue de Micropaléontologie 53, 29-51.

DOI 10.1016/j.revmic.2008.06.003

Casier, J.-G. \& Olempska, E. 2008. Middle Frasnian (Devonian) ostracods from the Frasnes railway section (Dinant Synclinorium, Belgium): taxonomy, biostratigraphy, paleoecology. Bulletin de l'Institut royal des Sciences naturelles de Belgique, Sciences de la Terre 78, 51-66.

CASIER, J.-G. \& PRÉAT, A. 1991. Evolution sédimentaire et Ostracodes de la base du Givétien à Resteigne (bord sud du Bassin de Dinant, Belgique). Bulletin de l'Institut royal des Sciences naturelles de Belgique, Sciences de la Terre 61, 157-177.

CAsier, J.-G. \& PrÉAt, A. 1996. Ostracodes et sédimentologie au passage Eifélien-Givétien dans la marbrière du Pic de Vissou (Montagne Noire, France). Bulletin du Centre de Recherche Exploration et Production Elf Aquitaine 20(2), 367-387.

CAsIER, J.-G. \& PRÉAT, A. 1997. Ostracodes et sédimentologie du Givétien à Ain Khira (Meseta nord-occidentale du Maroc). Revue de Paléobiologie 16(1), 151-167.

CAsier, J.-G. \& PrÉAt, A. 2006. Ostracods and lithofacies close to the Eifelian-Givetian boundary (Devonian) at Aisemont (Namur Synclinorium, Belgium). Bulletin de l'Institut royal des Sciences naturelles de Belgique, Sciences de la Terre 76, $5-29$.

CAsier, J.-G. \& PrÉAt, A. 2007. Ostracods and lithofacies of the Middle/Upper Devonian boundary Stratotype (Puech de la Suque, Montagne Noire, France). Bulletin de la Société Géologique de France 178(4), 293-304. DOI 10.2113/gssgfbull.178.4.293

CAsier, J.-G. \& PréAt, A. 2009. Late Givetian to Middle Frasnian ostracods from Nismes (Dinant Synclinorium, Belgium) and their lithological context. Bulletin de l'Institut royal des Sciences naturelles de Belgique, Sciences de la Terre 79, 87-115.

CAsier, J.-G. \& PréAt, A. 2013 (in press). Ostracodes et lithologie du stratotype de la Formation du Mont d'Haurs (Givétien, Synclinorium de Dinant). Revue de Paléobiologie.

Cocks, L.R.M. \& ToRsviK, T.H. 2006. European geography in a global context from the Vendian to the end of the Palaeozoic, 83-95. In GEe, D.G. \& STEPHENSON, R.A. (eds) European Lithosphere Dynamics, Geological Society, London, Memoirs 32.

Coen, M. 1985. Ostracodes givétiens de l'Ardenne. Mémoire de l'Institut Géologique de l'Université de Louvain 32, 1-48.

Coen-Aubert, M. 2004. Two new species of temnophyllids (Rugosa) from the Upper Givetian of Belgium. Bulletin de l'Institut royal des Sciences naturelles de Belgique, Sciences de la Terre 74, 19-36.

Coryell, H.N. \& Malkin, D.S. 1936. Some Hamilton ostracodes from Arkona, Ontario. American Museum Novitates 891, $1-20$.

Crasquin-Soleau, S., Vaslet, D. \& Le Nindre, Y.-M. 2005. Ostracodes as markers of the Permian/Triassic boundary in the Khuff Formation of Saudi Arabia. Palaeontology 48(4), 853-868. DOI 10.1111/j.1475-4983.2005.00476.x
Delo, D.M. 1930. Some Upper Carboniferous ostracoda from the Shale Basin of western Texas. Journal of Paleontology 4, $152-178$.

Dojen, C., Abboussalam, S.Z. \& Becker, R.T. 2010. Palaeoecological and biogeographical interpretation of Devonian ostracodes (Emsian to basal Givetian) of the Western Dra Valley, Morocco (sections Bou Tserfine, Rich Tamelougou and Hassi Mouf). Subcommission on Devonian Stratigraphy Newsletter 25, 37-40.

Egorov, V.G. 1950. Ostracoda of the Frasnian Stage of the Russian Platform. 1, Kloedenellidae. Trudy Vsesoyuznogo neftyanogo nauchno-issledovatel'skogo geologo-razvedochnogo instituta (VNIGRI), 1-40. [in Russian]

Egorov, V.G. 1953. Ostracoda of the Frasnian Stage of the Russian Platform. 2, Bairdiidae, Hollinidae, Kirkbyidae. Trudy Vsesoyuznogo neftyanogo nauchno-issledovatel'skogo geologo-razvedochnogo instituta (VNIGRI), 1-133. [in Russian]

Gouwy, S. \& Bultynck, P. 2003. Conodont based graphic correlation of the Middle Devonian formations of the Ardenne (Belgium): implications for stratigraphy and construction of a regional composite. Revista Española de Micropaleontología 35(3), 315-344.

Groos, H. 1969. Mitteldevonische Ostracoden zwischen Ruhr und Sieg (Rechtsrheinisches Schiefergebirge). Göttinger Arbeiten zur Geologie und Paläontologie 1, 1-110.

GüRICH, G. 1896. Das Paläozoikum des Polnischen Mittelgebirge. Verhandlungen der Russischen kaiserlichen Gesellschaft zu St. Petersburg II 32, 1-539.

Harlton, B.H. 1933. Micropaleontology of the Pennsylvanian Johns Valley shale of the Ouachila Mountains, Oklahoma, and its relationship to the Mississippian Caney shale. Journal of Paleontology 7, 3-29.

House, M.R. 1975. Faunas and time in the marine Devonian. Proceedings of the Yorkshire Geological Society 40, 459-490.

House, M.R. 1985. Correlation of mid-Palaeozoic ammonoid evolutionary events with global sedimentary perturbations. Nature 313(5997), 17-22. DOI 10.1038/313017a0

House, M.R. 2002. Strengh, timing, setting and cause of midPalaeozoic extinctions. Palaeogeography, Palaeoclimatology, Palaeoecology 181, 5-25.

DOI 10.1016/S0031-0182(01)00471-0

Hubert, B.L.M. \& Pinte, E. 2009. Detailed lithology, faunal abundance and correlations of the Cul d'Houille sections (Middle Devonian, Givetian, Avesnois, France). Annales de la Société Géologique du Nord 16(2érie), 79-89.

Johnson, J.G. 1970. Taghanic Onlap and the End of North American Devonian Provinciality. Geological Society of America Bulletin 81, 2077-2106.

DOI 10.1130/0016-7606(1970)81[2077:TOATEO]2.0.CO;2

JoNes, T.R. 1901. In CHAPMAN, F. (ed.) On some fossils of Wenlock age from Mulde, near Klinteberg, Gotland. Annals \& Magazine of Natural History 7, 141-160.

KegEL, W. 1932. Zur Kenntnis palaeozoischer Ostrakoden: 2. Bairdiidae aus dem Mitteldevon des Rheinischen Schiefergebirges. Jahrbuch der Preußischen geologischen Landesanstalt zu Berlin 52, 245-256.

Kellett, B. 1933. Ostracodes of the Upper Pennsylvanian and the Lower Permian strata of Kansas: 1. The Aparchitidae, 
Beyrichiidae, Glyptopleuridae, Kloedenellidae, Kirkbyidae, and Youngiellidae. Journal of Paleontology 7, 59-108.

KNIGHT, J.B. 1928. Some Pennsylvanian ostracodes from the Henrietta Formation of eastern Missouri, Part I and part II. Journal of Paleontology 2, 229-267, 318-337.

KRÖMmELBeIN, K. 1953. Ostracoden-Studien im Devon der Eifel, 3. Nachweis der polnischen Gattung Polyzygia und Poloniella im Mittel-Devon der Eifel. Senckenbergiana lethaea 34(1-3), 53-59.

KRÖMmELBEIN, K. 1954. Eine Ostracoden-Fauna aus der RiffEinlagerung im Plattenkalk der Paffrather Mulde (Givetium, Bergisches Land). Senckenbergiana lethaea 34, 247-258.

Kummerow, E. 1943. Die Ostracoden des Gratolithengesteins. Zeitschrift fur Geschibeforschung 19(1), 27-60.

Kummerow, E. 1953. Über oberkarbonische und devonische Ostracoden in Deutschland und in der Volksrepublik Polen. Geologie 7, 1-75.

Le Fèvre, J. 1963. Microfaunes de l'Emsien et du Dévonien moyen de la région Ougarta-Saoura (Sahara). 180 pp. PhD thesis, Université de Bordeaux, S.N.P.A., Centre de Recherches de Pau, France.

Le Fèvre, J. 1971. Paleoecological observations on Devonian Ostracodes from the Ougarta Hills (Algeria), 817-841. In Oertli, H.J. (ed.) Colloque sur la Paléoécologie des Ostracodes, Pau, 20-27 juillet 1970. Bulletin du Centre de Recherche de Pau, SPNA 5 suppl.

LethIERs, F. 1970. Quelques Ostracodes frasniens du Bas-Boulonnais (France). Annales de la Société Géologique du Nord 90(2), 69-75.

Lethiers, F. 1974. Biostratigraphie des Ostracodes dans le Dévonien supérieur du Nord de la France et de la Belgique. Newsletters on Stratigraphy 3(2), 73-79.

LETHIERS, F. 1982. Les ostracodes du Dévonien supérieur (Nord de la France, Belgique, Ouest du Canada). 489 pp. PhD thesis, Université des Sciences et Techniques de Lille, Lille, France.

LETHIERS, F. 1983a. Les extensions stratigraphiques des espèces d'ostracodes sur les plates-formes dévoniennes: le concept des répartitions sigmoïdales. Palaeogeography, Palaeoclimatology, Palaeocology 43, 299-312.

DOI 10.1016/0031-0182(83)90015-9

LethiERs, F. 1983b. Paléobiogéographie des faunes d'Ostracodes au Dévonien supérieur. Lethaia 16(1), 39-49.

DOI 10.1111/j.1502-3931.1983.tb01143.x

LETHIERS, F. 1984. Zonation du Dévonien supérieur par les ostracodes (Ardenne et Boulonnais). Revue de Micropaléontologie 27(1), 30-42.

Lethiers, F. \& Racheboeuf, P.R. 1993. Les ostracodes de la Formation de Kersadiou (Givétien du Massif Armoricain): biostratigraphie et paléoéologie. Geobios 26(5), 595-607. DOI 10.1016/0016-6995(93)80038-S

Magne, F. 1964. Données micropaléontologiques et stratigraphiques dans le Dévonien du Boulonnais (France) et du bassin de Namur (Belgique). 172 pp. PhD thesis, Université de Paris, S.N.P.A., Centre de Recherches de Pau, France.

Maillet, S. 2010. Les ostracodes du Givétien supérieur au bord sud du synclinorium de Dinant (Formation de Fromelennes, région de Givet, Ardennes): biostratigraphie, paléoécologie, recherche de bioévénements. $41 \mathrm{pp}$. Master thesis, Université des Sciences et Technologies de Lille, Lille, France.
Maillet, S. \& Milhau, B. 2010. Ostracods and Taghanic Event in Ardennes. The Palaeontological Association $54^{\text {th }}$ Annual Meeting, programme and abstracts, 17-20 December 2010, Ghent University, 58.

Maillet, S., Milhau, B. \& Hubert, B.L.M. 2010. New insight on the "Cul d'Houille" section near Flohimont (Givetian, Middle Devonian). Annales de la Société Géologique du Nord $17\left(2^{e}\right.$ série), 53-57.

Maillet, S., Milhau, B. \& Nicollin, J.-P. 2012. Middle/Upper Givetian ostracodes from the Aisne quarry (Heyd, Durbuy area, Belgium): stratigraphy, diversity, paleoecology and bioevents. $4^{\text {th }}$ Geologica Belgica Meeting, Brussels, September $10^{\text {th }}-14^{\text {th }}, 135$.

Maillet, S., Milhau, B. \& Pinte, E. 2011. The Fromelennes Formation in the type-area (Fromelennes, Ardennes, France). Annales de la Société Géologique du Nord 18 (2érie), 9-34.

Malec, J. \& RAcKi, G. 1993. Givetian and Frasnian ostracod associations from the Holy Cross Mountains. Acta Palaeontologica Polonica 37(2-4), 359-384.

Marshall, J.E.A., Brown, J.F. \& Astin, T.R. 2011. Recognizing the Taghanic Crisis in the Devonian terrestrial environment and its implications for understanding land-sea interactions. Palaeogeography, Palaeoclimatology, Palaeoecology 304, 165-183. DOI 10.1016/j.palaeo.2010.10.016

Matern, H. 1929. Die Ostracoden des Oberdevons. 1. Teil. Aparchitidae, Primitiidae, Zygobolbidae, Beyrichiidae, Kloedenellidae, Entomidae. Abhandlungen der grossherzoglichhessischen geologischen Landesanstalt 118, 1-100.

Matthew, G.F. 1886. On the Cambrian faunas of Cape Breton and Newfoundland. Transactions of the Royal Society of Canada 4(4), 29-84.

MAY, A. 1995. Relationship among sea-level fluctuation, biogeography and bioevents of the Devonian: an attempt to approach a powerful, but simple model for complex long-range control of biotic crises. Geolines 3, 38-49.

McGilL, P.C. 1966. Ostracods of probable late Givetian age from Slave Point Formation, Alberta. Bulletin of Canadian Petroleum Geology 14, 104-133.

Michel, P. 1972. Polyzygia Guerich (Ostracoda) in the Devonian of Asturias and Leon (Spain). Leidse Geologische Mededelingen 48(2), 207-273.

Milhau, B. 1983a. Valeur biostratigraphique et paléoécologique des ostracodes du Givétien supérieur de la région-type (Ardenne). Geobios 16(3), 347-359. DOI 10.1016/S0016-6995(83)80004-7

Milhau, B. 1983b. Ostracodes du Givétien supérieur du Boulonnais, corrélations avec l'Ardenne. Annales de la Société Géologique du Nord 102, 217-236.

Milhau, B. 1988. Ostracodes du Givétien de Ferques (Dévonien moyen, Boulonnais - France), 479-491. In BRICE, D. (ed.) Le Dévonien de Ferques, Bas Boulonnais (N. France). Biostratigraphie du Paléozoique 7.

Milhau, B. 1996. Les ostracodes au voisinage de la limite Eifelien-Givétien au Maroc: comparaison avec ceux d'Europe occidentale. Annales de la Société Géologique du Nord $4\left(2^{e}\right.$ série), 71-80.

Milhau, B., Casier, J.-G. \& Maillet, S. 2013 (in press). Les ostracodes. In BRICE, D. \& DE WEVER, P. (eds) Stratotype Givétien, collection Patrimoine géologique. 
MülLER, G.W. 1912. Ostracoda. Das Tierreich 31.434 pp. Friedländer, Berlin.

NARkiEwicz, K. \& Bultynck, P. 2010. The Upper Givetian (Middle Devonian) subterminus Conodont Zone in North America, Europe and North Africa. Journal of Paleontology 84(4), 588-625. DOI 10.1666/10-029.1

NeCKAyA, A.I. 1966. Ostracodes of the Ordovician and Silurian deposits of the U.S.S.R. (Familes Schmidtellidae, Rectellidae, Longisculidae and some new species from other families). Trudy Vsesoyuznogo neftyanogo nauchno-issledovatel'skogo geologo-razvedochnogo instituta (VNIGRI) 251, 1-104. [in Russian]

Olempska, E. 1979. Middle to Upper Devonian Ostracoda from the southern Holy Cross Mountains, Poland. Palaeontologia Polonica 40, 57-162.

Paeckelmann, W. 1913. Das Oberdevon des Bergischen Landes. Abhandlungen der grossherzoglich-hessischen geologischen Landesanstalt 70, 1-356.

Peterson, R.M. 1966. Ostracodes of genera Bufina and Euglyphella from the Middle Devonian of New York, Ohio, Michigan and Ontario. Journal of Paleontology 40(1), $1-20$.

Pinte, E. \& Mistiaen, B. 2009. Taghanic in Ardennes: Event or crisis? Prospectives en Paléontologie et Palynologie, $4^{\text {th }}$ APF congress, Lille, France, 66.

Pinte, E. \& Mistiaen, B. 2010. What is the impact of the Taghanic event on tabulate corals of the Ardennes? Third International Palaeontological Congress, London, June $28^{\text {th }}$-July $3^{\text {rd }} 2010$, Programme and abstracts, 315.

PoKORNÝ, V. 1951. The ostracods of the Middle Devonian Red Coral Limestones of Celechowice. Sbomík Státního geologického ústavu Československé republiky 17, 580-630.

PokoRnÝ, V. 1958. Grundzüge der zoologischen Mikropaläontologie. V.E.B. Deutscher Verlag der Wissenschaften 1, $1-582$.

Polenova, E.N. 1952. Ostracodes from the upper part of the Givetian Stage of the Russian Platform. Trudy Vsesoyuznogo neftyanogo nauchno-issledovatel'skogo geologo-razvedochnogo instituta (VNIGRI) 60, 65-156. [in Russian]

Polenova, E.N. 1953. Ostracoda from the Devonian deposits of the central Devonian field and the middle Volga area. Trudy Vsesoyuznogo neftyanogo nauchno-issledovatel'skogo geologo-razvedochnogo instituta (VNIGRI) 68, 1-157. [in Russian]

Polenova, E.N. 1960. Devonian ostracoda of the Kuznetsk Basin and the Munusinsk trough. Trudy Vsesoyuznogo neftyanogo nauchno-issledovatel'skogo geologo-razvedochnogo instituta (VNIGRI) 152, 1-139. [in Russian]

Posner, V.M. 1951. Stratigrafiya i mikrofauna nizhnego Karbona zapadnogo krila podmoskovnoi kotlovini. Trudy Vsesoyuznogo neftyanogo nauchno-issledovatel'skogo geologo-razvedochnogo instituta (VNIGRI), novaya seriya 56, 1-108.

Préat, A., Bultynck, P. \& Brice, D. 2006. Givetian. Geologica Belgica 9(1-2), 9-18.

Préat, A. \& Carliez, D. 1994. Microfaciès et cyclicité dans le Givétien supérieur de Fromelennes (synclinorium de Dinant, France). Annales de la Société géologique de Belgique 117(1), 227-243.

Préat, A. \& Mamet, B. 1989. Sédimentation de la plate-forme carbonatée givétienne franco-belge. Bulletin Centres Recherches Exploration-Production Elf Aquitaine 13(1), 47-86.

PřiBYL, A. 1951. On some new Ostracodes of the Lower and Middle Devonian of Bohemia. Bulletin international de l'Académie tchèque des Sciences 52(2), 1-43.

PřIBYL, A. 1953. The ostracodes of the Middle Devonian (Givetian) of Poland in the profile Grzegorzowice-Skaly in the Gory Swietokrzyskie (Holy Cross Mountains). Sborník Ústředního ústavu geologického 20,313-344.

Rozhdestvenskaya, A.A. 1959. Ostracodes from the Devonian terrigenous bed of the Western Bashkiria and their stratigraphic significance, 117-245. In ChIBRIKova, E.V. \& RozHDESTVEnSKAyA, A.A. (eds) Materialy po paleontologii $i$ stratigrafii Devonskikh $i$ bolee drevnikh otlozhenii Bashkirii. Izdatel'stvo Akademii nauk SSSR, Moskva.

RozhdestVEnskayA, A.A. 1962. Middle Devonian Ostracoda from the western slope of the southern Ural Mountains, preUralian trough and platform parts of Bashkiria, 169-349. In Tyazheva, A.P., Rozhdestvenskaya, A.A. \& Chibrikova, E.V. (eds) Brakhiopody, ostrakody i spory srednego $i$ verkhnego devona Bashkirii. Izdatel'stvo Akademii nauk SSSR, Moskva. [in Russian]

RoZHDESTVENSKAYA, A.A. 1972. Ostracods from the Upper Devonian of Bashkiria. 194 pp. Academy of Sciences SSSR, Bashkirian division, Nauka, Moskva. [in Russian]

SARS, G.O. 1888. Nye bitrag til kundskaben om middlehavets invertebratfauna, 4: Ostracoda mediterranea. Archiv Mathematik Naturvidenskab 12, 173-324.

Scotт, H.W. 1959. Type species of Paraparchites Ulrich and Bassler. Journal of Paleontology 33, 670-674.

Shaver, R.H. 1961. Family Bairdiocyprididae, Q364-Q367. In Moore, R.C. \& Pitrat, C.W. (eds) Treatise on Invertebrate Paleontology, Part Q, Arthropoda 3, Crustacea, Ostracoda. Geological Society of America \& University of Kansas Press, New York \& Lawrence.

Sintubin, M. 2008. L'Ardenne varisque: un témoin de la marge septentrionale de l'océan Rhéique, 26-29. In FAURe, R., LARDEAux, J.M. \& Rossi, P. (eds) La Chaîne varisque, Géochronique 105.

ŠLechtA, O. 1996. Ostracode faunas from the Lower/Middle Devonian section in Praha-Barrandov. Bulletin of the Czech Geological Survey 71(2), 135-144.

SoHn, J.G. 1961. Aechminella, Amphissites, Kirkbyella and related genera. U.S. Geological Survey Professional Paper 330-B, 105-160.

Sohn, I. \& Stover, L. 1961. Family Bufinidae, Q375-Q376. In Moore, C. (ed.) Treatise on Invertebrate Paleontology, Part $Q$, Arthropoda 3. Geological Society of America \& University of Kansas Press, Boulder \& Lawrence.

Stampfli, G.M., Von Raumer, J.F. \& Borel, G.D. 2002. Paleozoic evolution of the pre-Variscan terranes: From Gondwana to the Variscan collision, 263-280. In Martínez Catalán, J.R., Hatcher, R.D. JR., Arenas, R. \& Díaz García, F. (eds) Variscan-Appalachian dynamics: The building of the late Paleozoic basement. Geological Society of America Special Paper 364.

Swartz, F.M. 1936. Revision of the Primitiidae and Beyrichiidae, with new ostracoda from the lower Devonian of Pennsylvania. Journal of Paleontology 10(7), 541-586. 
UlRich, E.O. 1894. The lower Silurian Ostracoda of Minnesota. Geological and Natural History Survey of Minnesota 3(2), 629-693.

Ulrich, E.O. \& BassLer, R.S. 1908. New American Paleozoic Ostracoda. U. S. National Museum Proceedings (Washington) 35, 277-340. DOI 10.5479/si.00963801.35-1646.277

Van Pelt, H.L. 1933. Some ostracodes from the Bell shale, Middle Devonian of Michigan. Journal of Paleontology 7(3), 325-342.

ZaGORA, K. 1968. Ostracoden aus dem Grenzbereich Unter/Mitteldevon von Ostthürringen. Geologie 17(62), $1-91$.

Zaspelova, V.S. 1952. Ostracoda of the family Drepanellidae from Upper Devonian deposits of the Russian Platform. Trudy Vsesoyuznogo neftyanogo nauchno-issledovatel'skogo geologo-razvedochnogo instituta (VNIGRI), novaya seriya 60 (Mikrofauna SSSR 5), 157-216. [in Russian]

ZASPELOVA, V.S. 1959. Ostracoda and their value for the stratigraphy of the Devonian of the northwestern regions of the Russian Platform. Trudy Vsesoyuznogo neftyanogo nauchno-issledovatel'skogo geologo-razvedochnogo instituta (VNIGRI), novaya seriya 136 (Mikrofauna SSSR 10), 5-131. [in Russian]

ŻBıKowsKA, B. 1983. Middle to Upper Devonian ostracods from northwestern Poland and their stratigraphic significance. Palaeontologia Polonica 44, 3-108.

\section{Appendix 1. Systematic position of ostracodes taxa from the Fromelennes area.}

Class Ostracoda Latreille, 1802

Suborder Eridostracina Adamczak, 1961

Family Cryptophyllidae Adamczak, 1961

Cryptophyllus aff. materni Bassler \& Kellett, 1934 (Fig. 5S)

Cryptophyllus sp. 3 sensu Magne, 1964 (Fig. 5T)

Cryptophyllus sp. G sensu Magne, 1964 (Fig. 5U)

Cryptophyllus sp. B (Fig. 5V)

Eridoconcha? cf. granulifera Adamczak, 1961 (Fig. 5Z)

Eridoconcha? sp. A (Fig. 5AA)

Order Palaeocopida Henningsmoen, 1953

Suborder Palaeocopina Henningsmoen, 1953

Superfamily Beyrichioidea Matthew, 1886

Family Beyrichiidae Matthew, 1886

Kozlowskiella boloniensis Milhau, 1983 (Fig. 6O)

Kozlowskiella plana (Kummerow, 1953) (Fig. 6P, Q)

Kozlowskiella? sp. A (Fig. 6R)

Superfamily Aparchitoidea Jones, 1901

Family Rozhdestvenskayitidae McGill, 1966

Fellerites sp. A (Fig. 6F)

Family Aparchitidae Jones, 1901

Macronotella? sp. A (Fig. 6U)

Superfamily Drepanelloidea Ulrich \& Bassler, 1923

Family Aechminellidae Sohn, 1961

Balantoides brauni (Becker, 1968) (Fig. 5C)

Balantoides minimus (Lethiers, 1970) (Fig. 5D)

Balantoides sp. A (Fig. 5E)

Superfamily Nodelloidea Becker, 1968

Family Nodellidae Zaspelova, 1952

Nodella faceta Rozhdestvenskaya, 1972 (Fig. 6AB)

Nodella hamata Becker, 1968 (Fig. 6AC)

Superfamily Aechminacea Bouček, 1936

Family Aechminidae Bouček, 1936

Aechmina sp. A (Fig. 4J)

Superfamily Hollinoidea Swartz, 1936

Family Hollinidae Swartz, 1936

Subfamily Falsipollicinae Bless \& Jordan, 1971

Parabolbinella coeni Casier, 2011 (in Casier et al. 2011a) (Fig. 7M, N)

Semibolbina? sp. A (Fig. 8E)

Superfamily Kirkbyoidea Ulrich \& Bassler, 1906

Family Kirkbyellidae Sohn, 1961
Refrathella struvei Becker, 1967 (Fig. 7AG)

Family Amphissitidae Knight, 1928

Amphissites aff. parvulus (Paeckelmann, 1913) (Fig. 4K)

Amphissites cf. tener Becker, 1964 (Fig. 4L)

Family Scrobiculidae Posner, 1951

Scrobicula gracilis Casier \& Olempska, 2008 (Fig. 8D)

Roundyella patagiata (Becker, 1964) (Fig. 8A)

Roundyella? sp. A (Fig. 8B)

Superfamily Primitiopsacea Swartz, 1936

Family Primitiopsidae (Primitiopsinae) Swartz, 1936

Parapribylites hanaicus Pokorný, 1951 (Fig. 7K)

Parapribylites cf. costatus (Glebovskaya \& Zaspelova, 1959 in

Zaspelova 1959) (Fig. 7L)

Kielciella arduennensis Adamczak \& Coen, 1992 (Fig. 6N)

Kielciella fastigans (Becker, 1964)

Family Urftellidae Becker, 1970

Urftella cf. adamczaki Becker, 1970 (Fig. 8L)

?Family Pribylitidae Pokorný, 1958

Coryellina cybaea (Rozhdestvenskaya, 1959) (Fig. 5O)

Coryellina cf. curta (Rozhdestvenskaya, 1959) (Fig. 5P)

Coryellina? sp. A (Fig. 5Q)

Coryellina? sp. B (Fig. 5R)

Gravia schallreuteri Becker, 1970 (Fig. 6G)

Gravia? sp. A (Fig. 6H)

Superfamily Youngiellacea Kellett, 1933

Family Youngiellidae Kellett, 1933

Youngiella sp. 5 sensu Magne, 1964 (Fig. 8N)

Youngiella sp. A (Fig. 8M)

Suborder Paraparchitocopina Gramm \& Ivanov, 1975

Superfamily Paraparchitoidea Scott, 1959 (Sohn, 1971)

Family Paraparchitidae Scott, 1959

Samarella cf. laevinodosa Becker, 1964 (Fig. 8C)

Coeloenellina minima (Kummerow, 1953) (Fig. 5N)

Order Podocopida Müller, 1864

Suborder Podocopina Sars, 1866

Superfamily Bairdioidea Sars, 1888

Family Bairdiidae Sars, 1888

Bairdia paffrathensis Kummerow, 1953 (Fig. 4O, P)

Bairdia cf. plicatula Polenova, 1952 (Fig. 4Q)

Bairdia cf. siliklensis Rozhdestvenskaya, 1962 (Fig. 4R)

Bairdia sp. A (Fig. 4S) 
Bairdia sp. B (Fig. 4T)

Bairdia sp. C (Fig. 4U)

Bairdia sp. sensu Coen, 1985 (Fig. 4V)

Bairdiacypris aff. breuxensis Casier \& Olempska, 2008 (Fig. 4W)

Bairdiacypris sp. A (Fig. 4X)

Bairdiacypris sp. B (Fig. 4Y)

Fabalicypris? sp. A (Fig. 6E)

Acratia lucea sp. nov. (Fig. 4A-H)

Acratia sp. A (Fig. 4I)

Orthocypris? cristae sp. nov. (Fig. 7A-G)

Orthocypris cicatricosa Coen, 1985 (Fig. 7I)

Orthocypris cf. kummerowi Żbikowska, 1983 (Fig. 7H)

Superfamily Bairdiocypridoidea Shaver, 1961

Family Pachydomellidae Berdan \& Sohn, 1961

Tubulibairdia sp. A (Fig. 8G)

Microcheilinella aff. ventrosa Polenova, 1960 (Fig. 6V)

Microcheilinella aff. amaliae Kummerow, 1953 (Fig. 6W)

Microcheilinella cf. clava (Kegel, 1932) (Fig. 6X)

Microcheilinella sp. B (Fig. 6Y)

Microcheilinella sp. B sensu Casier \& Préat, 1991 (Fig. 6AA)

Microcheilinella sp. sensu Coen, 1985 (Fig. 6Z)

Ampuloides sp. 1 sensu Milhau, 1983 (Fig. 4M)

Family Rectellidae Neckaya, 1966

Rectella trapezoides Zaspelova, 1959 (Fig. 7AF)

Family Bairdiocyprididae Shaver, 1961

Bairdiocypris vastus Polenova, 1952 (Fig. 5A)

Bairdiocypris cf. symmetrica (Kummerow, 1953) (Fig. 5B)

Healdianella sp. A (Fig. 6I)

Silenites? sp. A (Fig. 8F)

Baschkirina? sp. indet. (Fig. 5F)

Family Macrocyprididae Müller, 1912

Macrocypris? sp. A (Fig. 6T)

Suborder Metacopina Sylvester-Bradley, 1961

Superfamily Healdioidea Harlton, 1933

Family Healdiidae Harlton, 1933

Cytherellina obliqua (Kummerow, 1953) (Fig. 5W)

Cytherellina cf. groosae Coen, 1985 (Fig. 5X)

Cytherellina cf. perlonga (Kummerow, 1953) (Fig. 5Y)

Superfamily Thlipsuroidea Ulrich, 1894

Family Quasillitidae Coryell \& Malkin, 1936

Quasillites fromelennensis Milhau, 1983 (Fig. 7X-AB)

Quasillites lecomptei Coen, 1985 (Fig. 7AD)
Quasillites cf. fromelennensis Milhau, 1983 (Fig. 7AE)

Quasillites? sp. A (Fig. 7AC)

Jenningsina catenulata (Van Pelt, 1933) (Fig. 6K)

Jenningsina heddebauti Milhau, 1983 (Fig. 6L)

Jenningsina paffrathensis Krömmelbein, 1954 (Fig. 6M)

Jefina kaisini Coen, 1985

Jefina cf. romei Coen, 1985 (Fig. 6J)

Ovatoquasillites cf. nismesensis Casier in Casier \& Préat (2009) (Fig. 7J)

Family Bufinidae Sohn \& Stover, 1961

Bufina schaderthalensis Zagora, 1968 (Fig. 5I)

Bufina aff. abbreviata Peterson, 1966 (Fig. 5G, H)

Family Ropolonellidae Coryell \& Malkin, 1936

Euglyphella europaea Coen, 1985 (Fig. 6A, B)

Plagionephrodes laqueus praelaqueus Casier \& Olempska, 2008 (Fig. 7O)

Family Thlipsuridae Ulrich, 1894

Polyzygia beckmanni antecedens Zagora, 1968 (Fig. 7T)

Polyzygia beckmanni beckmanni Krömmelbein, 1954 (Fig. 7U, V)

Polyzygia neodevonica Matern, 1929 (Fig. 7W)

Polyzygia cf. symmetrica Gürich, 1896

Asturiella sp. A (Fig. 4N)

Suborder Platycopina Sars, 1866

Superfamily Cytherelloidea Sars, 1866

Family Cavellinidae Egorov, 1950

Cavellina devoniana Egorov, 1950 (Fig. 5J)

Cavellina rhenana Krömmelbein, 1954 (Fig. 5K)

Cavellina cf. macella Kummerow, 1953 (Fig. 5L)

Cavellina cf. sp. II sensu Groos, 1969 (Fig. 5M)

Superfamily Kloedenelloidea Ulrich \& Bassler, 1908

Family Kloedenellidae Ulrich \& Bassler, 1908

Poloniella claviformis (Kummerow, 1953) (Fig. 7S)

Poloniella tertia Krömmelbein, 1953 (Fig. 7P-R)

Uchtovia abundans (Pokorný, 1951) (Fig. 8H)

Uchtovia materni Becker, 1971 (Fig. 8I)

Uchtovia refrathensis (Krömmelbein, 1954) (Fig. 8J)

Uchtovia? sp. A (Fig. 8K)

Evlanella germanica Becker, 1964 (Fig. 6C)

Evlanella sulcellina Becker, 1964 (Fig. 6D)

Family Knoxitidae Egorov, 1950

Knoxiella sp. 1 sensu Milhau, 1983 (Fig. 6S) 